\title{
Catalytic Promiscuity: Catecholase-like Activity and Hydrolytic DNA Cleavage Promoted by a Mixed-Valence $\mathrm{Fe}^{\mathrm{III}} \mathrm{Fe}^{\mathrm{II}}$ Complex
}

\author{
Ademir Neves, ${ }^{*}, a$ Adailton J. Bortoluzzi, ${ }^{a}$ Rafael Jovito, ${ }^{a}$ Rosely A. Peralta, ${ }^{a}$ \\ Bernardo de Souza, ${ }^{a}$ Bruno Szpoganicz, ${ }^{a}$ Antônio C. Joussef, ${ }^{a}$ Hernán Terenzi, ${ }^{b}$ \\ Patricia C. Severino, ${ }^{b}$ Franciele L. Fischer, ${ }^{b}$ Gerhard Schenk, ${ }^{c}$ Mark J. Riley, ${ }^{c}$ \\ Sarah J. Smith and Lawrence R. Gahan ${ }^{c}$
}
${ }^{a}$ LABINC, Departamento de Química and ${ }^{b}$ Centro de Biologia Molecular Estrutural, Departamento de Bioquímica, Universidade Federal de Santa Catarina, 88040-900 Florianópolis-SC, Brazil

${ }^{c}$ School of Chemistry and Molecular Biosciences, The University of Queensland, Brisbane 4072, Australia

\begin{abstract}
Os estudos sobre enzimas têm mostrado que existe uma relação clara entre a evolução enzimática e a propriedade de promiscuidade catalítica que elas podem apresentar. Com isto, o desenvolvimento de sistemas biomiméticos capazes de atuar de modo promíscuo, de forma similar a algumas enzimas, mostrou-se um novo desafio para os químicos bioinorgânicos. Neste trabalho, reportamos a estrutura de raios X e os estudos em solução e de promiscuidade catalítica do complexo $\left[(\mathrm{bpbpmp}) \mathrm{Fe}^{\mathrm{II}}(\mu-\mathrm{OAc})_{2} \mathrm{Fe}^{\mathrm{II}}\right]\left(\mathrm{ClO}_{4}\right),(\mathbf{1})$, contendo o ligante binucleante não-simétrico 2-\{[(2-hidroxibenzil)(2-piridilmetil)aminometil]-4-metil-6-[bis(2-piridilmetil)aminometil]\}fenol ( $\mathrm{H}_{2}$ bpbpmp). Estudos de titulações potenciométrica e espectrofotométrica e cinéticos mostraram que esse composto de coordenação gera espécies ativas capazes de clivar o dsDNA (DNA de fita dupla) hidroliticamente, com um aumento de $1,9 \times 10^{8}$ na taxa de reação em comparação com a reação não catalisada, e capazes de oxidar o 3,5-di-terc-butilcatecol (3,5-dtbc), com $k_{\text {cat }}=1,16 \times 10^{-2} \mathrm{~s}^{-1}$ e $K_{\mathrm{M}}=7,1 \times 10^{-4} \mathrm{~mol} \mathrm{~L}^{-1}$. Assim, o complexo 1 apresenta atividades de hidrolase e oxidoredutase, sendo um interessante modelo sintético para estudos de promiscuidade catalítica.
\end{abstract}

Catalytic promiscuity has emerged as an important property of many enzymes since the relationship of this property to enzymatic evolution became clear. Simultaneously, the development of suitable biomimetic catalytic systems capable of mimicking the promiscuous catalytic properties of such enzymes represents a new challenge for bioinorganic chemists. In this paper we report on the X-ray structure, the solution studies and the promiscuous catalytic activity of the mixed-valence complex $\left[\left(\right.\right.$ bpbpmp)Fe $\left.e^{\mathrm{III}}(\mu-\mathrm{OAc})_{2} \mathrm{Fe}^{\mathrm{II}}\right]\left(\mathrm{ClO}_{4}\right),(\mathbf{1})$, containing the unsymmetrical dinucleating ligand 2-\{[(2-hydroxybenzyl)(2-pyridylmethyl)aminomethyl]-4-methyl-6-[bis(2-pyridylmethyl) aminomethyl] \} phenol ( $\mathrm{H}_{2}$ bpbpmp). Potentiometric and spectrophotometric titrations and kinetics studies showed that this coordination compound generates active species that promote hydrolytic cleavage of double strand DNA (dsDNA), with a rate enhancement of $1.9 \times 10^{8}$ over the non-catalyzed reaction, as well as promote oxidation of 3,5-di-tert-butylcatechol (3,5-dtbc), with $k_{\text {cat }}=1.16 \times 10^{-2} \mathrm{~s}^{-1}$ and $K_{\mathrm{M}}=7.1 \times 10^{-4} \mathrm{~mol} \mathrm{~L}^{-1}$. Thus, complex 1 shows both hydrolase and oxidoreductase activities and can be regarded as a man-made model for studying catalytic promiscuity.

Keywords: mixed-valence $\mathrm{Fe}^{\mathrm{III}} \mathrm{Fe}^{\mathrm{II}}$ complex, unsymmetrical ligand, catalytic promiscuity, diester and DNA cleavage, catecholase activity

\section{Introduction}

Catalytic promiscuity means, in the broadest sense, the ability of a given natural or non-natural active site

This paper is dedicated to our friend Professor Icaro Moreira in memoriam *e-mail: ademir@qmc.ufsc.br to catalyze more than one chemical transformation. It constitutes a very important property of many enzymes, having a natural role in evolution and, occasionally, in the biosynthesis of secondary metabolites. ${ }^{1-7}$ For example, it has been demonstrated that vanadium-dependent chloroperoxidase shows phosphatase activity when 
vanadate is not present, indicating that its active site is very similar to that of the acid phosphatases. ${ }^{8}$ On the other hand, it was found that an acid phosphatase from plants (in contrast to the kidney bean purple acid phosphatase (PAP)) uniquely exhibits chloroperoxidase activity with loss of phosphatase activity when orthovanadate is added to the apo form of the enzyme. ${ }^{9}$ Although these activities constitute very different overall reactions, they involve enzyme-bound species that are structurally related. Furthermore, it has been demonstrated that the PAP isolated from tomato may act as a bifunctional enzyme that operates in the hydrolysis of phosphate-esters and also displays significant alkaline peroxidase activity with the involvement of reactive oxygen species. ${ }^{10}$ Indeed, several plant PAPs have been reported to be expressed in response to pathogen attack or elicitor treatment. ${ }^{11,12}$ Nevertheless, no catecholase activity for any of the well characterized PAPs has as yet been described. While several enzymes displaying catalytic promiscuity have been the subject of recent related investigations, ${ }^{1-7}$ there are few examples of synthetic analogues which exhibit such multifunctional activities. ${ }^{13-18}$

In recent years, considerable attention has been devoted to the synthesis, X-ray structural analysis and physicochemical characterization of structural and functional dinuclear $\mathrm{Fe}^{\mathrm{III}} \mathrm{M}^{\mathrm{II}}$ mimetics for the active site of metallohydrolases such as purple acid phosphatase. ${ }^{19-21}$ In particular, we have successfully developed a general method for the preparation of mixed-valence homoand hetero-dinuclear $\mathrm{M}^{\mathrm{III}} \mathrm{M}^{\mathrm{II}}$ complexes, using the unsymmetrical ligand ( $\mathrm{H}_{2}$ bpbpmp) $2-\{[(2$-hydroxybenzyl) (2-pyridylmethyl)aminomethyl]-4-methyl-6-[bis(2pyridylmethyl)aminomethyl] $\}$ phenol (Scheme 1).22-32

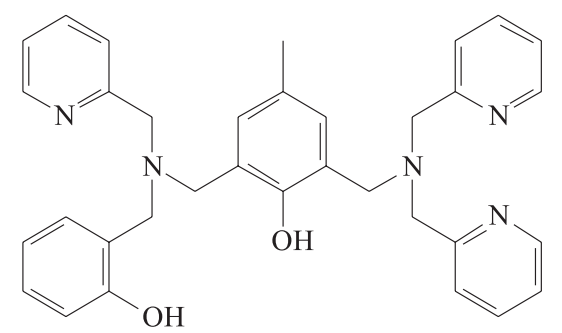

Scheme 1. Schematic representation of $\mathrm{H}_{2}$ bpbpmp.

For example, it has been established that the [(bpbpmp) $\left.\mathrm{Fe}^{\mathrm{III}}(\mu-\mathrm{OAc})_{2} \mathrm{Fe}^{\mathrm{II}}\right]\left(\mathrm{ClO}_{4}\right) \cdot \mathrm{H}_{2} \mathrm{O}$ complex, (1), is a good model for the electrochemical properties of uteroferrin, with a reduction potential for the $\mathrm{Fe}^{\mathrm{III}} \mathrm{Fe}^{\mathrm{III}}$ to $\mathrm{Fe}^{\mathrm{III}} \mathrm{Fe}^{\mathrm{II}}$ couple of $380 \mathrm{mV}$ (versus the normal hydrogen electrode, NHE), which compares well with the $344 \mathrm{mV}$ measured for uteroferrin at $\mathrm{pH} 4.1$ via direct electrochemistry and $367 \mathrm{mV}$ at $\mathrm{pH} 5$ via microcoulometry.9., 33,34 It has also been well documented that complex $\mathbf{1}$ and its corresponding oxidized complex [(bpbpmp) $\left.\mathrm{Fe}^{\mathrm{III}}(\mu-\mathrm{OAc})_{2} \mathrm{Fe}^{\mathrm{III}}\right]\left(\mathrm{ClO}_{4}\right)_{2}$, (2), are good models for the resonance Raman properties of mammalian PAPs in their reduced and oxidized forms, respectively. ${ }^{30}$ In addition, to understand the spectral signatures of the dinuclear center and to relate these to the di-iron enzyme uteroferrin, spectroelectrochemical, spectroscopic, and computational studies, and phosphataselike reactivity of the $\left[(\text { bpbpmp }) \mathrm{Fe}^{\mathrm{III}}(\mu-\mathrm{OAc})_{2} \mathrm{Fe}^{\mathrm{II}}\right]^{+}$ion complex have also been reported. ${ }^{31}$ Very recently, the $\left[(\text { bpbpmp }) \mathrm{Fe}^{\mathrm{II}}(\mu-\mathrm{OAc})_{2} \mathrm{Fe}^{\mathrm{II}}\right]^{+}$complex has been used as an electrochemical biomimetic sensor for the determination of phenolic compounds. ${ }^{32}$

In this study, we describe the X-ray structure and solution studies of the mixed-valence complex [(bpbpmp) $\left.\mathrm{Fe}^{\mathrm{III}}(\mu-\mathrm{OAc})_{2} \mathrm{Fe}^{\mathrm{II}}\right]\left(\mathrm{ClO}_{4}\right) \cdot \mathrm{H}_{2} \mathrm{O},(\mathbf{1})$, which is able to cleave phosphodiester bonds of the activated substrate bis(2,4dinitrophenyl)phosphate (2,4-bdnpp $)^{35}$ and of DNA itself, but also shows significant catalytic activity in the oxidation of the model substrate 3,5-di-tert-butylcatechol (3,5-dtbc) and can thus be considered as a promiscuous man-made catalyst.

\section{Experimental}

\section{Materials and measurements}

All reagents of high purity grade were purchased from commercial sources and used as received. In the characterization of $\mathrm{H}_{2}$ bpbpmp and its complexes, and in the kinetic studies, spectroscopic grade solvents from Merck, dried using molecular sieves, were used.

The potentiometric studies were carried out with a Micronal $375 \mathrm{pH}$ meter fitted with blue-glass and calomel reference electrodes calibrated to read $-\log \left[\mathrm{H}^{+}\right]$directly, designated as $\mathrm{pH}$. Bidistilled water in the presence of $\mathrm{KMnO}_{4}$ was used to prepare $\mathrm{CH}_{3} \mathrm{CN}(1: 1 \mathrm{v} / \mathrm{v})$ solutions. The electrode was calibrated using the data obtained from a potentiometric titration of a known volume of a standard $0.0100 \mathrm{~mol} \mathrm{~L}^{-1} \mathrm{HCl}$ solution with standard $0.100 \mathrm{~mol} \mathrm{~L}^{-1}$ $\mathrm{KOH}$. The temperature was kept at $25.00 \pm 0.05{ }^{\circ} \mathrm{C}$, and the ionic strength was adjusted to $0.100 \mathrm{~mol} \mathrm{~L}^{-1}$ by addition of $\mathrm{KCl}$. The experimental solutions were titrated with $0.100 \mathrm{~mol} \mathrm{~L}^{-1}$ standard $\mathrm{CO}_{2}$-free $\mathrm{KOH}$. Equilibrium measurements were taken using solutions containing $0.05 \mathrm{mmol}$ of complex. The experiments were performed on $50.00 \mathrm{~mL}$ of the $\mathrm{CH}_{3} \mathrm{CN}: \mathrm{H}_{2} \mathrm{O}(1: 1 \mathrm{v} / \mathrm{v})$ solution in a thermostated cell purged with argon, using $0.100 \mathrm{~mol} \mathrm{~L}^{-1}$ $\mathrm{KOH}$ solutions. The experiments were carried out in triplicate. Computations of the triplicates were all carried out with the BEST7 program, and the species diagrams were obtained with SPE and SPEPLOT programs. ${ }^{36}$ 
Complexes $\mathbf{1}$ and $\mathbf{2}$ were also titrated spectrophotometrically. All titrations were carried out under an argon atmosphere at $25^{\circ} \mathrm{C}$ in $1: 1(\mathrm{v} / \mathrm{v}) \mathrm{CH}_{3} \mathrm{CN}: \mathrm{H}_{2} \mathrm{O}$. The $\mathrm{pH}$ was first adjusted with $\mathrm{HCl}$ and the complex titrated with successive additions of $\mathrm{CO}_{2}$ free $\mathrm{KOH} 0.124 \mathrm{~mol} \mathrm{~L}^{-1}$. At each measured $\mathrm{pH}$, an aliquot was removed to record the UV-Vis spectrum.

A dark red crystal was selected from the sample of complex 1 and fixed at the end of a glass fiber for X-ray analysis. Crystallographic measurements of complex $\mathbf{1}$ were carried out with an Enraf-Nonius CAD4 diffractometer with graphite-monochromated $\mathrm{Mo}_{\mathrm{K}} \mathrm{K}_{\alpha}$ radiation, at room temperature. Cell parameters were determined from 25 carefully centered reflections using a standard procedure. ${ }^{37}$ All data were corrected for Lorentz and polarization effects. ${ }^{38} \mathrm{~A}$ semi-empirical absorption correction based on the azimuthal scans of seven appropriate reflections was also applied to the collected intensities with the PLATON program, ${ }^{39,40}$ with maximum and minimum transmission factors of 0.873 and 0.791 , respectively. The structure was solved by direct methods and refined by full-matrix leastsquares methods using SIR $97^{41}$ and SHELXL9 $97^{42}$ programs, respectively. All non-hydrogen atoms were refined anisotropically. $\mathrm{H}$ atoms attached to $\mathrm{C}$ atoms were placed at their idealized positions, with C-H distances and $U_{\text {eq }}$ values taken from the default settings of the refinement program. The water molecule $\mathrm{H}$ atoms were found from a Fourier difference map and treated with the riding model. Two oxygen atoms of the perchlorate counterion are disordered over two alternative positions. The site occupancies of $0.555(14)$ and $0.445(14)$ for the disordered atoms were refined and the geometric parameters around the chlorine atom were constrained. Further selected crystallographic data are summarized in Table 1.

\section{Syntheses}

The unsymmetric dinucleating ligand $\mathrm{H}_{2}$ bpbpmp was prepared accordingly to procedures previously described in the literature. ${ }^{23}$

\section{$\left[(\right.$ bpbpmp $\left.) \mathrm{Fe}^{I I I}(\mu-\mathrm{OAc})_{2} \mathrm{Fe}^{I I}\right]\left(\mathrm{ClO}_{4}\right) \cdot \mathrm{H}_{2} \mathrm{O},(\mathbf{1})$}

$0.5 \mathrm{mmol}$ of $\mathrm{H}_{2}$ bpbpmp were dissolved in $10 \mathrm{~mL}$ of $\mathrm{CH}_{3} \mathrm{CN}$ under argon. To this solution were added, respectively, $1 \mathrm{mmol}$ of $\mathrm{Fe}\left(\mathrm{ClO}_{4}\right)_{2} \cdot 6 \mathrm{H}_{2} \mathrm{O}$ and $2 \mathrm{mmol}$ of $\mathrm{NaOAc}$ in $\mathrm{MeOH}(10 \mathrm{~mL})$ also under argon. The resulting solution became deep purple. Finally, $5 \mathrm{~mL}$ of diisopropyl ether in the presence of air were added to the purple solution, which was kept in the refrigerator. After $24 \mathrm{~h}$ crystals suitable for X-ray crystallography were formed, which were collected by filtration $(0.32 \mathrm{~g}, 70 \%)$. Elemental
Analysis for $\mathrm{C}_{38} \mathrm{H}_{41} \mathrm{ClFe}_{2} \mathrm{~N}_{5} \mathrm{O}_{11}\left(890.91 \mathrm{~g} \mathrm{~mol}^{-1}\right)$ : Found $\mathrm{C}$, 51.56; H, 4.60; N, 7.78. Calculated C, 51.23; H, 4.64; N, $7.86 \%$. The compound is stable in air in the solid state. (Caution! As with all perchlorate salts, samples should be handled with care.)

$\left[(\right.$ bpbpmp $\left.) \mathrm{Fe}^{I I I}(\mu-\mathrm{OAc})_{2} \mathrm{Fe}^{I I I}\right]\left(\mathrm{ClO}_{4}\right)_{2} \cdot 3 \mathrm{CH}_{3} \mathrm{OH} \cdot 3 \mathrm{H}_{2} \mathrm{O}$

To a solution of $\mathrm{Fe}\left(\mathrm{ClO}_{4}\right)_{3} \cdot 9 \mathrm{H}_{2} \mathrm{O}(2.0 \mathrm{mmol})$ in $20 \mathrm{~mL}$ of methanol, sodium acetate trihydrate $(2.5 \mathrm{mmol})$ and $\mathrm{H}_{2}$ bpbpmp (1.07 mmol) were added. The clear dark blue solution was heated to $40{ }^{\circ} \mathrm{C}$ and stirred for $10 \mathrm{~min}$ at ambient atmosphere. After cooling of the solution to room temperature, a blue microcrystalline precipitate was formed, which was filtered off and washed with 2-propanol and ether $(0.73 \mathrm{~g}, 65 \%)$. Elemental Analysis for $\mathrm{C}_{41} \mathrm{H}_{57} \mathrm{Cl}_{2} \mathrm{Fe}_{2} \mathrm{~N}_{5} \mathrm{O}_{20}\left(1121.17 \mathrm{~g} \mathrm{~mol}^{-1}\right)$ : Found $\mathrm{C}, 44.3$; $\mathrm{H}, 4.58 ; \mathrm{N}, 6.24$. Calculated C, 43.87; H, 5.12; N, 6.24\%.

\section{Kinetics}

Catecholase-like activity toward the oxidation of the model substrate 3,5-di-tert-butylcatechol (3,5$\mathrm{dtbc)}$ was investigated. The experiments were followed spectrophotometrically on a Varian Cary50 Bio spectrophotometer connected to a computer, by monitoring the increase in the 3,5-di-tert-butyl-quinone (3,5-dtbq) characteristic absorption band at $400 \mathrm{~nm}$ over time. The conversion of the reaction rate units was carried out using $\varepsilon=1760 \mathrm{~L} \mathrm{~mol}^{-1} \mathrm{~cm}^{-1}$ (measured in the reaction conditions) for 3,5-di-tert-butylquinone, and the initial concentration of complex.

The experiments were carried as follows: a stock solution of the complex was prepared in methanol (16 h earlier), saturated with argon $\left(4.4 \times 10^{-4} \mathrm{~mol} \mathrm{~L}^{-1}\right)$. A stock solution of the substrate was also prepared in methanol ([3.5-dtbc] = $8.26 \times 10^{-2} \mathrm{~mol} \mathrm{~L}^{-1}$ ). To a $4 \mathrm{~mL}$ cuvette, $100 \mu \mathrm{L}$ of argonsaturated buffer and $100 \mu \mathrm{L}$ of $\mathbf{1}$ were added. Subsequently, $\mathrm{O}_{2}$-saturated methanol, deionized water and substrate (20-200 $\mu \mathrm{L}$ ) were added to complete $3.0 \mathrm{~mL}$ (giving the proportion $1.8 \mathrm{~mL}$ methanol : $1.2 \mathrm{~mL}$ water, $\mathrm{v} / \mathrm{v}$ ).

The initial rate was obtained from the slope of the absorbance $v s$. time plot over the first $10 \mathrm{~min}$ of reaction. Each experiment was performed at least three times, and the obtained plots were analyzed by the initial rate method. A kinetic treatment using nonlinear Michaelis-Menten approach was applied.

The influence of the $\mathrm{pH}$ on the catalyzed oxidation of the 3,5-di-tert-butylcatechol was determined over the $\mathrm{pH}$ range of 4.4 to 9.0 . Reactions were performed using the following conditions in the cuvette: air saturated 
$\mathrm{CH}_{3} \mathrm{OH} / \mathrm{H}_{2} \mathrm{O}, 3: 2 \mathrm{v} / \mathrm{v},[\mathbf{1}]=1.39 \times 10^{-5} \mathrm{~mol} \mathrm{~L}^{-1},[3,5-\mathrm{dtbc}]=$ $2.77 \times 10^{-3} \mathrm{~mol} \mathrm{~L}^{-1}$, [buffer] $=3.3 \times 10^{-2} \mathrm{~mol} \mathrm{~L}^{-1}$ (Buffer $=$ MES, 2-[ $N$-morpholine] ethanesulfonic acid, or TRIS, tris(hydroxymethyl)aminomethane). Dependence of the reaction rates on $[3,5-\mathrm{dtbc}]$ was determined at $\mathrm{pH}$ 6.0, in a methanol:water $(3: 2, \mathrm{v} / \mathrm{v})$ solution. Conditions: $[1]=1.46 \times 10^{-5} \mathrm{~mol} \mathrm{~L}^{-1} ;[3,5-\mathrm{dtbc}]=0.5-5.5 \times 10^{-3} \mathrm{~mol} \mathrm{~L}^{-1}$, [buffer $]=3.3 \times 10^{-2} \mathrm{~mol} \mathrm{~L}^{-1}$ (buffer $=$ MES).

To determine which reduced oxygen species (hydrogen peroxide or water) was formed during the reaction, mixtures were prepared as in the kinetics experiments. After $1 \mathrm{~h}$ of reaction an equal volume of $\mathrm{H}_{2} \mathrm{SO}_{4}\left(5 \times 10^{-3} \mathrm{~mol} \mathrm{~L}^{-1}\right)$ was added. The quinone was washed twice with dichloromethane $(2 \times 3 \mathrm{~mL})$. To a $2 \mathrm{~mL}$ aliquot of the aqueous layer a KI solution $\left(1 \mathrm{~mL}, 0.30 \mathrm{~mol} \mathrm{~L}^{-1}\right)$ was added. Finally, ammonium molybdate $\left(0.1 \mathrm{~mol} \mathrm{~L}^{-1}\right)$ solution was added in catalytic amounts to specifically accelerate the formation of $\mathrm{I}_{3}^{-}$in the presence of $\mathrm{H}_{2} \mathrm{O}_{2}$. The increase in the $\mathrm{I}_{3}^{-}$absorption band at $353 \mathrm{~nm}\left(\varepsilon=26,000 \mathrm{~L} \mathrm{~mol}^{-1} \mathrm{~cm}^{-1}\right)$ was monitored by UV-Vis spectroscopy. ${ }^{43-45}$ The reaction without oxygen was prepared under the kinetic conditions and the absorbance increase at $400 \mathrm{~nm}$ due to quinone release was not observed.

\section{DNA extraction}

Plasmid DNA (pBSKII) (Stratagene) was produced in Escherichia coli and purified with HiSpeed Maxiprep Kit (Qiagen) following the protocol described by the manufacturer.

\section{DNA cleavage under anaerobic and aerobic conditions}

Complex 1 solutions were diluted in acetonitrile in an argon-filled glove bag to avoid Fe oxidation. A two-step procedure was used to obtain deoxygenated water, piperazine-1,4-bis(2-ethanesulfonic acid) (PIPES) buffer and ethylenediaminetetraacetic acid (edta). A parallel experiment with the oxidative cleavage system $\left[\mathrm{Fe}(\text { edta) }]_{2} / \mathrm{DTT}\right.$ (dithiothreitol) was used to demonstrate the deoxygenation procedure efficiency. ${ }^{46,47}$ DNA cleavage experiments were performed in a final volume of $20 \mu \mathrm{L}$ containing $35 \mu \mathrm{mol} \mathrm{L}{ }^{-1}$ bp (DNA base pairs) pBSK II plasmid DNA, complex 1 [40, 80 and $160 \mu \mathrm{mol} \mathrm{L}^{-1}$ ], 25\% acetonitrile (v/v) and $25 \mathrm{mmol} \mathrm{L}^{-1}$ PIPES buffer, $\mathrm{pH}$ 6.0. Reaction mixtures were incubated at $50{ }^{\circ} \mathrm{C}$ for $2 \mathrm{~h}$ in a sealed argon-filled vacuum desiccator.

Identical complex $\mathbf{1}$ solutions as prepared in argon-filled bags were used for the reactions under aerobic conditions. All other conditions and procedures were essentially the same as those described for anaerobic reactions.
Reactions were stopped by chilling tubes on ice and adding $4 \mu \mathrm{L}$ of ice-cold loading-buffer (50\% glycerol, $0.2 \mathrm{~mol} \mathrm{~L}^{-1}$ edta, $0.05 \%$ bromophenol blue). Samples were submitted to agarose gel electrophoresis and stained with ethidium bromide. Resulting gels were digitalized with a photo-documentation system (UVP, CA, USA) and DNA bands were quantified using LabWorks software version 4.0 (UVP).

\section{Kinetics DNA assays}

DNA cleavage reactions were performed at $50{ }^{\circ} \mathrm{C}$ in $25 \mathrm{mmol} \mathrm{L}^{-1}$ PIPES (pH 6.0), using $35 \mu \mathrm{mol} \mathrm{L}^{-1}$ bp (DNA base pairs) pBSK II plasmid DNA at concentrations of complex 1 ranging from 0 to $160 \mu \mathrm{mol} \mathrm{L}^{-1}$, in a final volume of $160 \mu \mathrm{L}$. Aliquots of $20 \mu \mathrm{L}$ were withdrawn at different time intervals (0-60 min) and were analyzed as described for the DNA cleavage..$^{22,48}$

\section{Reaction mechanism}

Cleavage experiments to understand the reaction mechanism were carried out with potential inhibiting agents such as a hydroxyl radical scavenger dimethyl sulfoxide (dmso), a singlet oxygen scavenger (sodium azide, $\mathrm{NaN}_{3}$ ) and a minor groove binder (distamycin) ${ }^{7,49-51}$

Reactions in the presence of the above compounds were carried out in $20 \mu \mathrm{L}$ final volume, containing: $35 \mu \mathrm{mol} \mathrm{L} \mathrm{L}^{-1}$ bp (plasmid DNA), in 25 mmol L-1 PIPES, pH 6.0, for $1 \mathrm{~h}$ at $50{ }^{\circ} \mathrm{C}$ (other conditions are described in the Figure legends). Reactions were stopped by chilling tubes on ice and adding $4 \mu \mathrm{L}$ of ice-cold loading-buffer. Samples were analyzed in $0.8 \%$ agarose gel.

\section{Results and Discussion}

\section{Synthesis of $\mathbf{1}$ and $\mathbf{2}$ and crystal structure of $\mathbf{1}$}

Reaction of one equivalent of the unsymmetrical ligand $\mathrm{H}_{2}$ bpbpmp with two equivalents of $\left[\mathrm{Fe}\left(\mathrm{OH}_{2}\right)_{6}\right]$ $\left(\mathrm{ClO}_{4}\right)_{2}$ in the presence of NaOAc in a 1:1 mixture of $\mathrm{CH}_{3} \mathrm{CN}$ and methanol results in the formation of the title complex $\left[(\right.$ bpbpmp $\left.) \mathrm{Fe}^{\mathrm{III}}(\mu-\mathrm{OAc})_{2} \mathrm{Fe}^{\mathrm{II}}\right]\left(\mathrm{ClO}_{4}\right) \cdot \mathrm{H}_{2} \mathrm{O}$ (1). The properties determined by elemental, UV-Vis and electrochemical analysis are in agreement with the composition previously proposed for $1 .{ }^{29}$ Crystals of $\mathbf{1}$ suitable for X-ray crystallography were obtained by slow diffusion of diisopropyl ether in a methanolic solution of the title complex. On the other hand, when the reaction of one equivalent of $\mathrm{H}_{2}$ bpbpmp was carried out with two equivalents of iron(III) perchlorate in the presence 
of excess perchlorate, the oxidized dinuclear complex $\left[\left(\right.\right.$ bpbpmp) $\left.\mathrm{Fe}^{\mathrm{III}}(\mu-\mathrm{OAc})_{2} \mathrm{Fe}^{\mathrm{III}}\right]\left(\mathrm{ClO}_{4}\right) \cdot 3 \mathrm{CH}_{3} \mathrm{COH} \cdot 3 \mathrm{H}_{2} \mathrm{O}(\mathbf{2})$ was obtained. This complex was characterized by elemental analysis, electronic spectroscopy, and electrochemistry/ spectroelectrochemistry. All attempts to obtain suitable crystals of $\mathbf{2}$ for X-ray analysis were unsuccessful.

The structure of complex $\mathbf{1}$ consists of discrete dinuclear $\left[\mathrm{Fe}^{\mathrm{III}}(\text { bpbpmp })(\mu-\mathrm{OAc})_{2} \mathrm{Fe}^{\mathrm{II}}\right]^{+}$cations, uncoordinated perchlorate anions and one molecule of water in the crystallographic asymmetric unit. An ORTEP drawing of $\mathbf{1}$ with its atom-labeling scheme is shown in Figure 1. Selected bond distances and angles are given in Table 2.

The structure of the cation $\left[\mathrm{Fe}^{\mathrm{III}}(\mathrm{bpbpmp})(\mu-\mathrm{OAc})_{2} \mathrm{Fe}^{\mathrm{II}}\right]^{+}$ in 1 is similar to that determined for the corresponding $\mathrm{BF}_{4}^{-}$ salt. ${ }^{31}$ Briefly, in the structure of $\left[\mathrm{Fe}^{\mathrm{III}}(\mathrm{bpbpmp})(\mu-\mathrm{OAc})_{2} \mathrm{Fe}^{\mathrm{II}}\right]^{+}$ the metal centers are bridged by the phenolate oxygen atom of the bpbpmp ${ }^{2-}$ ligand and by two exogenous acetate ligands, as has been observed in numerous isostructural complexes containing the same ligand. ${ }^{22-29}$ As expected for a dinuclear mixed-valence complex containing the unsymmetrical bpbpmp ${ }^{2-}$ ligand, the coordination sphere of the $\mathrm{Fe}^{\mathrm{III}}$ is completed by two nitrogen atoms from the tertiary amine (N1) and pyridyl (N22) groups, and by a terminal phenolate oxygen $(\mathrm{O} 10)$, while the $\mathrm{Fe}^{\mathrm{II}}$ is on the softer side of bpbpmp ${ }^{2-}$, coordinated by three nitrogen atoms, pyridyl $\mathrm{N} 32$ and N42 and tertiary amine N2.

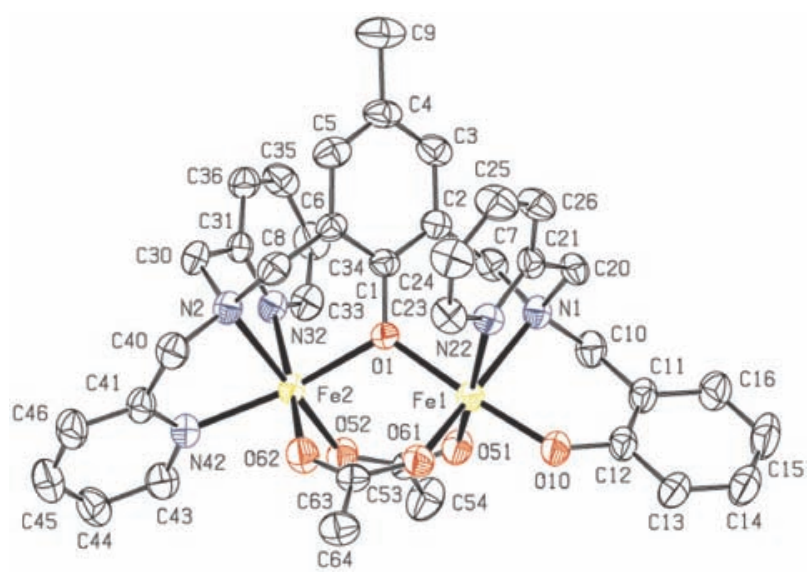

Figure 1. ORTEP projection of the molecular structure of the cation of complex 1. Ellipsoids are shown at the $40 \%$ probability level. $\mathrm{H}$ atoms are omitted for clarity.

The bridging $\mathrm{O}_{\text {phenolate }}$ is coordinated unsymmetrically to the two metal centers, with the bond distances $\mathrm{Fe}^{\mathrm{III}}-\mathrm{O}=2.005(3)$ and $\mathrm{Fe}^{\mathrm{II}}-\mathrm{O}=2.102(3) \AA$ being slightly longer than those observed in the mixed-valence complex $\left[\mathrm{Fe}^{\mathrm{III}} \mathrm{Fe}^{\mathrm{II}}(\mathrm{bpmp})(\mathrm{OPr})_{2}\right]^{2+}\left(\mathrm{Fe}^{\mathrm{III}}-\mathrm{O}=1.943(2)\right.$ and $\mathrm{Fe}^{\mathrm{II}}-\mathrm{O} 1=2.090(2) \AA$ ) containing the symmetric Hbpmp (2,6-bis[(bis(2-pyridylmethyl)amino)methyl]4-methylphenol) ligand. ${ }^{29} \mathrm{As}$ in the analogous $\mathrm{Fe}^{\mathrm{III}} \mathrm{M}^{\mathrm{II}}$
Table 1. Crystal data and structure refinement for complex $\mathbf{1}$

\begin{tabular}{|c|c|}
\hline Empirical formula & $\mathrm{C}_{38} \mathrm{H}_{41} \mathrm{ClFe}_{2} \mathrm{~N}_{5} \mathrm{O}_{11}$ \\
\hline Formula weight & 890.91 \\
\hline Temperature & 293(2) K \\
\hline Wavelength & $0.71073 \AA$, Mo-K ${ }_{\alpha}$ \\
\hline Crystal system, space group & monoclinic, $P 2_{1} / n$ \\
\hline \multirow[t]{4}{*}{ Unit cell dimensions } & $a=12.746(3) \AA$ \\
\hline & $b=18.309(4) \AA$ \\
\hline & $c=17.077(3) \AA$ \\
\hline & $\beta=93.87(3)^{\circ}$ \\
\hline Volume & $3976.0(14) \AA^{3}$ \\
\hline $\mathrm{Z}$ & 4 \\
\hline Calculated density & $1.488 \mathrm{Mg} / \mathrm{m}^{3}$ \\
\hline$\mu$ & $0.863 \mathrm{~mm}^{-1}$ \\
\hline $\mathrm{F}(000)$ & 1844 \\
\hline Crystal size & $0.47 \times 0.20 \times 0.16 \mathrm{~mm}$ \\
\hline Theta range for data collection & $2.06^{\circ}$ to $25.00^{\circ}$ \\
\hline Index ranges & $0 \leq \mathrm{h} \leq 15,0 \leq \mathrm{k} \leq 21,-20 \leq 1 \leq 20$ \\
\hline Reflections collected / unique & $7331 / 6996\left(\mathrm{R}_{\mathrm{int}}=0.0346\right)$ \\
\hline Refinement method & Full-matrix least-squares on $\mathrm{F}^{2}$ \\
\hline Data / restraints / parameters & $6996 / 140 / 533$ \\
\hline Goodness of fit $\left(\mathrm{F}^{2}\right)$ & 0.974 \\
\hline$R$ indices $[I>2 \sigma(I)]$ & $\mathrm{R}_{1}=0.0431, \mathrm{wR}_{2}=0.1024$ \\
\hline $\mathrm{R}$ indices (all data) & $\mathrm{R}_{1}=0.1275, \mathrm{wR}_{2}=0.1145$ \\
\hline Largest diff. peak and hole & 0.364 and -0.375 e. $\AA^{-3}$ \\
\hline
\end{tabular}

complexes $\left(\mathrm{M}^{\mathrm{II}}=\mathrm{Zn}, \mathrm{Cu}, \mathrm{Ni}, \mathrm{Mn}\right)$, the terminal phenolate coordinated to the $\mathrm{Fe}^{\mathrm{III}}$ is trans to the bridging phenolate. The metal-metal distance (3.5041(13) $\AA$ ) as well as the $\mathrm{Fe}^{\mathrm{III}}-\mathrm{O}-\mathrm{Fe}^{\mathrm{II}}$ angle $\left(117.14(13)^{\circ}\right)$ in the $\mathrm{Fe}^{\mathrm{III}} \mathrm{Fe}^{\mathrm{II}}$ complex are similar to those observed in all of the isostructural $\mathrm{Fe}^{\mathrm{III}} \mathrm{M}^{\mathrm{II}}$ complexes $\left(3.470-3.510 \AA\right.$ and $\left.115-119^{\circ}\right) .^{22-29}$ Additionally, the terminal phenoxo- $-\mathrm{Fe}^{\mathrm{III}}-\mathrm{O}_{\text {phenolate }}$ bond length $(1.902(3) \AA)$ in $\mathbf{1}$ is slightly longer than the corresponding bond in the $\mathrm{Fe}^{\mathrm{III}} \mathrm{Zn}^{\mathrm{II}}$ complex $(1.890 \AA) .{ }^{52}$

\section{Solution studies of $\mathbf{1}$ and $\mathbf{2}$}

Potentiometric titration studies of the complex $\left[\mathrm{Fe}^{\mathrm{II}}(\right.$ bpbpmp $\left.)(\mu-\mathrm{OAc})_{2} \mathrm{Fe}^{\mathrm{II}}\right] \mathrm{ClO}_{4}(\mathbf{1})$ in $1: 1$ acetonitrile/ buffer have been described previously and showed the presence of four protonation equilibria, two of which $\left(\mathrm{p} K_{\mathrm{a} 2}=4.13\right.$ and $\left.\mathrm{p} K_{\mathrm{a} 4}=7.53\right)$ are catalytically relevant for the hydrolysis of phosphate diester bonds. ${ }^{31}$ Results are summarized in Table 3, with the kinetic $\mathrm{p} K_{\mathrm{a}} \mathrm{s}$ of $\mathbf{1}$ for comparison.

Considering that the oxidized form of complex 2 in aqueous solution is the origin of the catalytically active 
Table 2. Selected bond lengths ( $\AA$ ) and angles (degree) for complex 1

\begin{tabular}{lccc}
\hline Fe1-O10 & $1.902(3)$ & Fe2-O52 & $2.032(3)$ \\
Fe1-O61 & $1.963(3)$ & Fe2-O1 & $2.102(3)$ \\
Fe1-O1 & $2.005(3)$ & Fe2-O62 & $2.127(3)$ \\
Fe1-O51 & $2.022(3)$ & Fe2-N42 & $2.143(3)$ \\
Fe1-N22 & $2.192(3)$ & Fe2-N32 & $2.217(3)$ \\
Fe1-N1 & $2.223(4)$ & Fe2-N2 & $2.219(3)$ \\
Fe1-Fe2 & $3.5041(13)$ & & \\
\hline O10-Fe1-O61 & $90.20(13)$ & O52-Fe2-O62 & $95.75(13)$ \\
O10-Fe1-O1 & $175.60(12)$ & O1-Fe2-O62 & $88.35(12)$ \\
O61-Fe1-O1 & $94.17(12)$ & O52-Fe2-N42 & $100.75(13)$ \\
O10-Fe1-O51 & $89.91(13)$ & O1-Fe2-N42 & $163.83(13)$ \\
O61-Fe1-O51 & $100.12(13)$ & O62-Fe2-N42 & $84.41(13)$ \\
O1-Fe1-O51 & $89.80(12)$ & O52-Fe2-N32 & $93.25(13)$ \\
O10-Fe1-N22 & $95.36(13)$ & O1-Fe2-N32 & $90.16(12)$ \\
O61-Fe1-N22 & $92.31(13)$ & O62-Fe2-N32 & $170.96(13)$ \\
O1-Fe1-N22 & $83.99(12)$ & N42-Fe2-N32 & $94.73(13)$ \\
O51-Fe1-N22 & $166.49(13)$ & O52-Fe2-N2 & $170.46(13)$ \\
O10-Fe1-N1 & $87.53(13)$ & O1-Fe2-N2 & $89.41(12)$ \\
O61-Fe1-N1 & $168.00(13)$ & O62-Fe2-N2 & $93.12(13)$ \\
O1-Fe1-N1 & $88.09(12)$ & N42-Fe2-N2 & $76.61(13)$ \\
O51-Fe1-N1 & $91.67(13)$ & N32-Fe2-N2 & $77.95(13)$ \\
N22-Fe1-N1 & $76.19(13)$ & Fe1-O1-Fe2 & $117.14(13)$ \\
O52-Fe2-O1 & $94.33(11)$ & & \\
\hline & & & \\
\hline
\end{tabular}

species for the oxidation of catechols (vide infra), we also carried out potentiometric titration of this complex under experimental conditions identical to those employed for complex 1. As can be observed in Figure 2, four mol of $\mathrm{KOH}$ were neutralized in the $\mathrm{pH}$ range of 2.4-10.9. Fitting the data with the BEST program results in the following deprotonation constants: $\mathrm{p} K_{\mathrm{a} 2}=3.14, \mathrm{p} K_{\mathrm{a} 3}=4.22$, $\mathrm{p} K_{\mathrm{a} 4}=6.45$ and $\mathrm{p} K_{\mathrm{a} 5}=9.65$. It is well known that in related
$\mathrm{M}^{\mathrm{III}}(\mu-\mathrm{OAc})_{2} \mathrm{M}^{\mathrm{II}}$ dinuclear complexes, the bridging carboxylate groups dissociate resulting in the formation of $\mathrm{Fe} \mathrm{III}^{\mathrm{II}}-\mathrm{OH} / \mathrm{OH}_{2}$ species when in aqueous solution. Thus, the four-deprotonation/protonation equilibrium steps for complex $\mathbf{2}$ are proposed in Scheme 2 with the corresponding species distribution given in Figure 2. It is assumed that when 2 is dissolved in aqueous solution at $\mathrm{pH} 2.4$, two acetate groups are released, leading to the $\left[\left(\mathrm{OH}_{2}\right) \mathrm{Fe}^{\mathrm{II}}(\mu-\mathrm{OH})\right.$ $\left.\mathrm{Fe}^{\mathrm{III}}\left(\mathrm{OH}_{2}\right)\right]$ species (structure A in Scheme 2).

Deprotonation of the water molecule $\left(\mathrm{p} K_{\mathrm{a} 2}=3.14\right)$ coordinated to the $\mathrm{Fe}^{\mathrm{III}}$ center containing the softer terminal tridentate group (one amine and two pyridine) leads to the formation of the $\left[\left(\mathrm{OH}_{2}\right) \mathrm{Fe}^{\mathrm{III}}(\mu-\mathrm{OH}) \mathrm{Fe}^{\mathrm{III}}(\mathrm{OH})\right]$ species (structure B in Scheme 2). This observation is based mainly on the fact that the $\mathrm{Fe}^{\mathrm{III}}$ center bound by three nitrogens of bpbpmp ${ }^{2-}$ is a stronger Lewis acid than the $\mathrm{Fe}^{\mathrm{III}}$ center coordinated by the harder $\mathrm{N}_{2} \mathrm{O}$-donor pendant arm containing

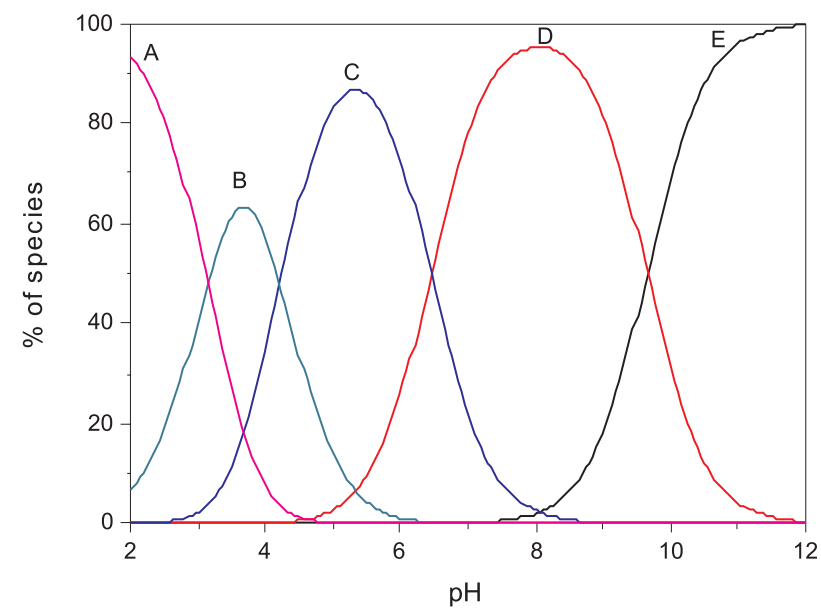

Figure 2. Species diagram for the potentiometric titration of the complex $\left[\mathrm{Fe}^{\mathrm{III}}(\mathrm{bpbpmp})(\mu-\mathrm{OAc})_{2} \mathrm{Fe}^{\mathrm{III}}\right]\left(\mathrm{ClO}_{4}\right)_{2} \cdot \mathrm{H}_{2} \mathrm{O}$ in $\mathrm{CH}_{3} \mathrm{CN}: \mathrm{H}_{2} \mathrm{O}$ 1:1. A: $\left[\left(\mathrm{OH}_{2}\right)\right.$ $\left.\mathrm{Fe}^{\mathrm{III}}(\mu-\mathrm{OH}) \mathrm{Fe}^{\mathrm{III}}\left(\mathrm{OH}_{2}\right)\right] ; \mathrm{B}$ : $\left[(\mathrm{OH}) \mathrm{Fe}^{2 \mathrm{III}}(\mu-\mathrm{OH}) \mathrm{Fe}^{\mathrm{III}}\left(\mathrm{OH}_{2}\right)\right] ; \mathrm{C}:[(\mathrm{OH})$ $\left.\mathrm{Fe}^{\mathrm{III}}(\mu-\mathrm{O}) \mathrm{Fe}^{\mathrm{III}}\left(\mathrm{OH}_{2}\right)\right] ; \mathrm{D}:\left[(\mathrm{OH}) \mathrm{Fe}^{\mathrm{III}}(\mu-\mathrm{O}) \mathrm{Fe}^{\mathrm{III}}(\mathrm{OH})\right] ; \mathrm{E}:\left[(\mathrm{OH}) \mathrm{Fe}^{\mathrm{III}}(\mu-\mathrm{O})\right.$ $\left.\mathrm{Fe}^{\mathrm{III}}(\mathrm{OH})_{2}\right]$

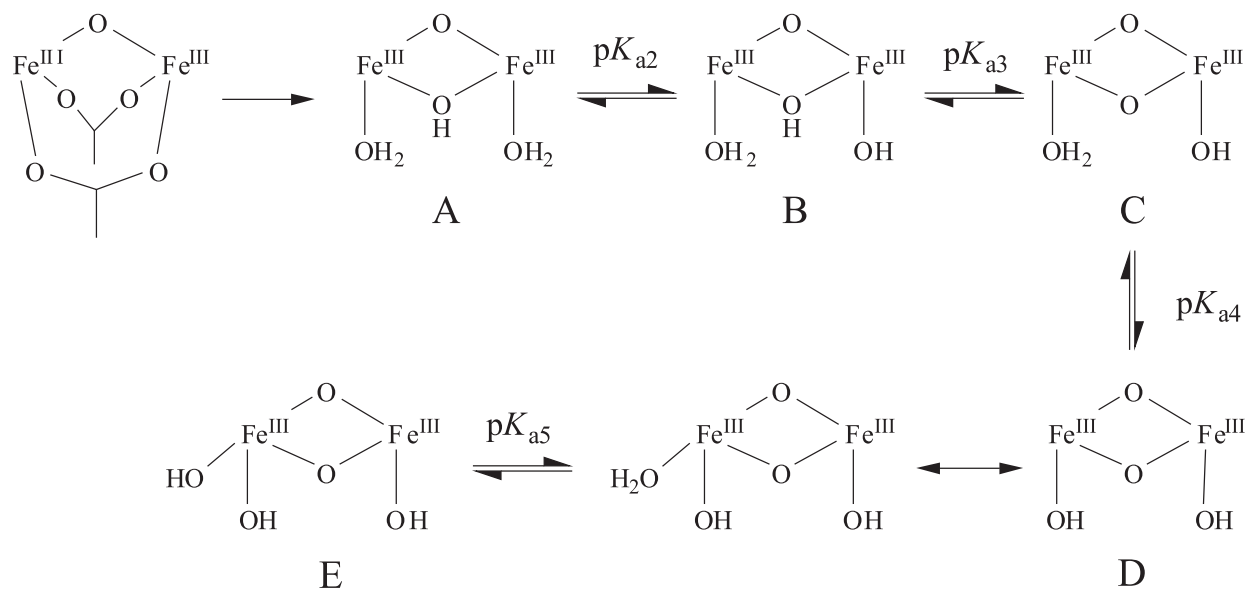

Scheme 2. Proposed equilibria for the complex [ $\mathrm{Fe}^{\mathrm{III}}($ bpbpmp $\left.)(\mu-\mathrm{OAc})_{2} \mathrm{Fe}^{\mathrm{III}}\right]^{2+}$ in $\mathrm{CH}_{3} \mathrm{CN}: \mathrm{H}_{2} \mathrm{O}$ 1:1. 
the terminal phenolate group. The $\mathrm{p} K_{\mathrm{a} 3}$ of 4.22 is attributed to dissociation of the bridging $\mu-\mathrm{OH}$ group which results in the formation of $\left[\left(\mathrm{OH}_{2}\right) \mathrm{Fe}^{\mathrm{II}}(\mu-\mathrm{O}) \mathrm{Fe}^{\mathrm{III}}(\mathrm{OH})\right]$ (structure $\mathrm{C}$ in Scheme 2) as one of the catalytically active species in the oxidation of catechols (vide infra). This $\mathrm{p} K_{\mathrm{a}}$ value is around $1.5 \mathrm{pH}$ units lower than the corresponding $\mathrm{p} K_{\mathrm{a}}$ determined in the mixed-valence $\mathrm{Fe}^{\mathrm{II}} \mathrm{Fe}^{\mathrm{II}}$ complex $\mathbf{1}$ and can be explained in terms of a higher Lewis acidity exerted by two $\mathrm{Fe}^{\text {IIII centers }}$ on the bridging $\mu-\mathrm{OH}$ group in complex 2 . Deprotonation of the water molecule $\left(\mathrm{p} K_{\mathrm{a} 4}=6.45\right)$ terminally coordinated to the $\mathrm{Fe}^{\mathrm{III}}$ center which contains the harder tridentate $\mathrm{N}_{2} \mathrm{O}$-donor group (one amine, one pyridine and one phenolate) leads to the formation of the $\left[(\mathrm{OH}) \mathrm{Fe}^{\mathrm{III}}(\mu-\mathrm{O}) \mathrm{Fe}^{\mathrm{III}}(\mathrm{OH})\right]$ species (structure D in Scheme 2) which is the most active catalyst in the oxidation of catechols. Again, as expected, this $\mathrm{p} K_{\mathrm{a} 4}=6.45$ is approximately one $\mathrm{pH}$ unit lower when compared to the protonation/deprotonation equilibrium found for the corresponding $\mathrm{Fe}^{\mathrm{II}}-\mathrm{OH}_{2}$ bond in the mixed-valence complex 1. Moreover, it is also important to note that this $\mathrm{p} K_{\mathrm{a} 4}$ value is in good agreement with the $\mathrm{p} K_{\mathrm{a}}$ of 7.0 determined for the dissociation of the second $\mathrm{Fe}^{\mathrm{III}}$-bound water molecule in a dinuclear $\mathrm{Fe}^{\mathrm{III}}$ complex which contains a similar NO-donor set as that proposed for the $\left[\left(\mathrm{OH}_{2}\right) \mathrm{Fe}^{\mathrm{III}}(\mu-\mathrm{O}) \mathrm{Fe}^{\mathrm{III}}(\mathrm{OH})\right]$ species. ${ }^{53}$ Finally, a fourth deprotonation/protonation equilibrium at $\mathrm{p} K_{\mathrm{as}}=9.65$ was observed, despite the fact that in the $\left[(\mathrm{OH}) \mathrm{Fe}^{\mathrm{III}}(\mu-\mathrm{O}) \mathrm{Fe}^{\mathrm{III}}(\mathrm{OH})\right]$ species there appears to be no ionizable protons under these experimental conditions. We tentatively suggest the substitution of one pyridine group bound to one of the $\mathrm{Fe}^{\mathrm{IIII}}$ centers by one water molecule with subsequent deprotonation of this water molecule as being responsible for this equilibrium. ${ }^{53}$

UV-visible spectroscopy is another tool employed to identify species in equilibrium and can be very useful to assign the catalytically active species in solution. Moreover, it should be noted that complexes $\mathbf{1}$ and $\mathbf{2}$ display ligandto-metal charge transfer (LMCT) processes which are very sensitive to any electronic change (e.g. Lewis acidity) in the metal centers. Thus, we used electronic spectroscopy to further confirm the catalytically active species of $\mathbf{1}$ and 2 under kinetic conditions.
Spectrophometric titration of the mixed-valence complex 1 reveals four protonation/deprotonation constants which are comparable to those obtained from the potentiometric experiments (Table 3, Figure S1). ${ }^{31}$ In general, hypsochromic shifts are detected (Figure 3) when the $\mathrm{pH}$ of the solution rises, suggesting that the replacement of $\mathrm{Fe}^{\mathrm{III}}-\mathrm{OH}_{2}$ by $\mathrm{Fe}^{\mathrm{III}}-\mathrm{OH}$, or of $\mathrm{Fe}^{\mathrm{III}}(\mu-\mathrm{OH}) \mathrm{Fe}^{\mathrm{III}}$ by $\mathrm{Fe}^{\mathrm{III}}(\mu-\mathrm{O}) \mathrm{Fe}^{\mathrm{III}}$ in the systems in equilibrium does affect the energy of the LMCT processes. This is probably due to a lower order of Lewis acidity of the $\mathrm{Fe}^{\mathrm{III}}$-centers when the stronger donor hydroxo or oxo groups are coordinated, so that the $t_{2 g}$ orbitals in these species are at higher energy than the $t_{2 g}$ orbitals in the $\mathrm{Fe}^{\mathrm{III}}-\mathrm{OH}_{2}$ complexes. Similarly, spectrophotometric titration of the oxidized form of complex 2 also demonstrates that the $\lambda_{\text {max }}$ of the LMCT is strongly influenced by the $\mathrm{pH}$ of the solution (Figure S2, Figure S3). However, in this case only three reliable $\mathrm{p} K_{\mathrm{a}}$ values (Table 3 ) could be obtained in the $\mathrm{pH}$ range of 2.4-10.9, which are in good agreement with those calculated in the potentiometry studies.

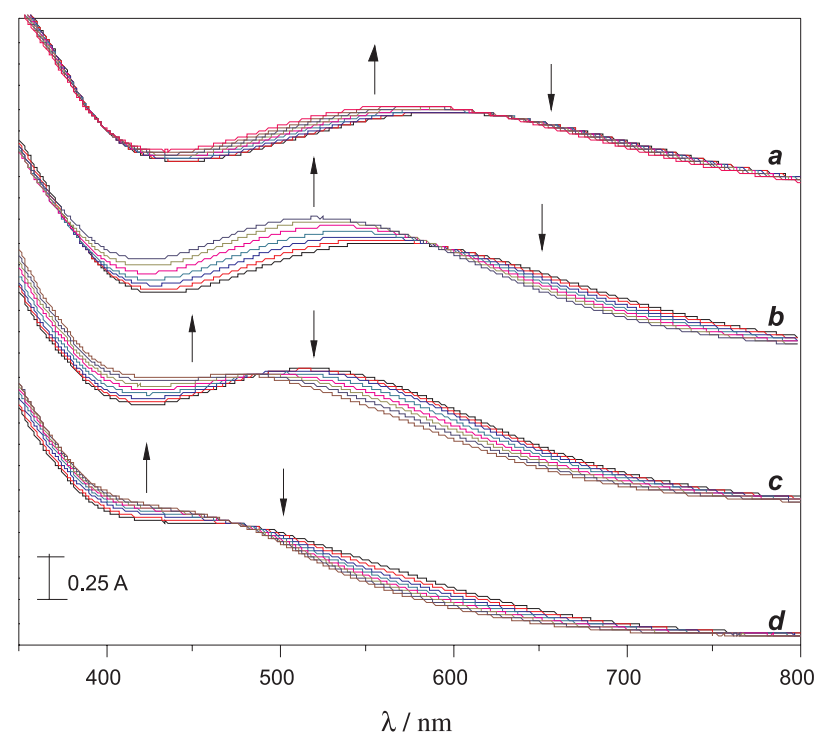

Figure 3. Spectral changes of the complex [ $\left.\mathrm{Fe}^{\mathrm{III}}(\mathrm{bpbpmp})(\mu-\mathrm{OAc})_{2} \mathrm{Fe}^{\mathrm{II}}\right]$ $\mathrm{ClO}_{4}$ during spectrophotometric titration. The spectra were recorded in $\mathrm{CH}_{3} \mathrm{CN}: \mathrm{H}_{2} \mathrm{O}$ 1:1 at successive $\mathrm{pH}$. [complex] $=3 \times 10^{-4} \mathrm{~mol} \mathrm{~L}^{-1}$. $\mathrm{pH}$ range $\boldsymbol{a}: 3.3-3.8 ; \boldsymbol{b}: 3.9-5.3 ; \boldsymbol{c}: 5.8-6.9 ; \boldsymbol{d}: 7.2-10.2$

Table 3. Summary of $\mathrm{p} K_{\mathrm{a}}$ values in $\mathrm{CH}_{3} \mathrm{CN}: \mathrm{H}_{2} \mathrm{O} 1: 1$ at $25^{\circ} \mathrm{C}$

\begin{tabular}{|c|c|c|c|c|c|}
\hline \multicolumn{2}{|c|}{ Complex 1} & \multicolumn{2}{|c|}{ Complex 2} & \multirow{2}{*}{$\begin{array}{c}\text { kinetic } \\
\text { (hydrolysis) }^{a}\end{array}$} & \multirow{2}{*}{$\begin{array}{c}\text { kinetic } \\
\text { (oxidation) }\end{array}$} \\
\hline potentiometric $^{\mathrm{a}}$ & spectrophotometric $^{\mathrm{b}}$ & potentiometric & spectrophotometric & & \\
\hline 3.02 & 3.47 & $*$ & $*$ & - & - \\
\hline 4.13 & 4.44 & 3.14 & nd & 4.74 & - \\
\hline 5.76 & 6.47 & 4.22 & 3.95 & - & 5.0 \\
\hline 7.53 & 7.97 & 6.45 & 6.56 & 7.54 & 6.7 \\
\hline- & - & 9.65 & 9.22 & - & - \\
\hline
\end{tabular}

${ }^{\mathrm{a}}$ Data from reference $11 ;{ }^{\mathrm{b}}$ This work; $*$ There is no equivalent $\mathrm{p} K_{\mathrm{a}}$ for this complex; nd: Not determined. 


\section{Kinetics}

In recent years, it has been demonstrated that many enzymes are able to catalyze distinctly more than one chemical reaction. This ability, called catalytic promiscuity, may be related to different kinds of bond formation or cleavage or different catalytic pathways or even both., ${ }^{1,54}$ Biomimetic models can be more susceptible to catalytic promiscuity, since they do not have a complex structure as do enzymes. In this regard, biomimetic models are expected to be much more accessible to different substrates and more dependent on the environmental conditions.

The catalytic promiscuity of the complex [Fe ${ }^{\mathrm{III}}(\mathrm{bpbpmp})$ $\left.(\mu-\mathrm{OAc})_{2} \mathrm{Fe}^{\mathrm{II}}\right] \mathrm{ClO}_{4}$, (1), was evaluated by testing its hydrolase-like activity in the cleavage of DNA and its catecholase-like activity toward the oxidation of the model substrate 3,5-di-tert-butylcatechol (3,5-dtbc) ${ }^{31}$ The phosphatase-like activity of $\mathbf{1}$ in the hydrolysis of the model substrate bis-2,4-dinitrophenylphosphate (2,4-bdnpp) has been demonstrated very recently. ${ }^{31}$

The catecholase activity of complexes $\mathbf{1}$ and $\mathbf{2}$ was determined using the substrate 3,5-di-tert-butylcatechol by following spectrophotometrically the absorbance increase due to the formation of 3,5-di-tert-butylquinone $\left(\lambda_{\max }=400 \mathrm{~nm}\right)$, under conditions of excess substrate. It is important to note that there is no reaction (not even one cycle) using $\mathbf{1}$ as the catalyst during a period of three hours in the absence of oxygen. However, after this time, if the cuvettes were opened to allow the entrance of oxygen, the reaction begins immediately. Therefore, the kinetics data obtained suggest the formation of an oxidized form of $\mathrm{Fe}^{\mathrm{III}} \mathrm{Fe}^{\mathrm{III}}$ as the catalyst, which can be obtained through oxidation of $\mathbf{1}$ in the presence of air or through chemical oxidation of 1 with $\mathrm{H}_{2} \mathrm{O}_{2}$ or from the dissolution of the complex $\mathbf{2}$ in kinetic conditions. Indeed, the spectrum of $\mathbf{1}$ under kinetic conditions without the substrate shows the disappearance of the intervalence band centered at $1100 \mathrm{~nm}$, indicating that the species $\left[\left(\mathrm{OH}_{2}\right)\right.$ $\left.\mathrm{Fe}^{\mathrm{III}}(\mu-\mathrm{O}) \mathrm{Fe}^{\mathrm{II}}(\mathrm{OH})\right]$ is oxidized to complex $\left[\left(\mathrm{OH}_{2}\right) \mathrm{Fe}^{\mathrm{III}}(\mu-\mathrm{O})\right.$ $\left.\mathrm{Fe}^{\mathrm{III}}(\mathrm{OH})\right]$ in the presence of air (Figure S4).

The $\mathrm{pH}$-dependence of the oxidation reaction of 3,5-dtbc was evaluated from $\mathrm{pH} 4.4$ to 9.0 and, as can be observed in Figure 4, there are two distinct kinetic behaviors indicating the presence of different catalysts. Initially, the reaction rate increases only slightly and reaches a plateau in the $\mathrm{pH}$ range 6.0-6.5. A further increase in $\mathrm{pH}$ results in an almost uninterrupted increase in the initial rate $\mathrm{V}_{0}$, suggesting that a second species is acting as the catalyst. However, from the inflection points in the plot given in Figure 4, the $\mathrm{p} K_{\mathrm{a}} \mathrm{s}$ at 5.0 and 6.7 are only tentatively attributed given the small increase in reactivity in the $\mathrm{pH}$ range 4.3-6.5 and the poor definition of the plateau at $\mathrm{pH}$ 7.0. Even so, these $\mathrm{p} K_{\mathrm{a}}$ values are in relatively good agreement with those obtained from the potentiometric and spectrophotometric experiments (4.2 and 6.5), thus suggesting that the $\left[\left(\mathrm{OH}_{2}\right)\right.$ $\left.\mathrm{Fe}^{\mathrm{III}}(\mu-\mathrm{O}) \mathrm{Fe}^{\mathrm{III}}(\mathrm{OH})\right](\mathrm{C})$ and $\left[(\mathrm{OH}) \mathrm{Fe}^{\mathrm{III}}(\mu-\mathrm{O}) \mathrm{Fe}^{\mathrm{III}}(\mathrm{OH})\right]$ (D) in Scheme 2 are most probably the catalytically active species in the oxidation of 3,5-dtbc. Indeed, the observed $\mathrm{pH}$ dependence of the reaction may be due to the successive deprotonation of $\mathrm{Fe}^{\mathrm{III}}$-coordinated water molecules, and probably the $\mathrm{Fe}^{\mathrm{III}}-\mathrm{OH}$ groups are able to interact with catechol promoting the deprotonation of the substrate and concomitant coordination to the metal centers.

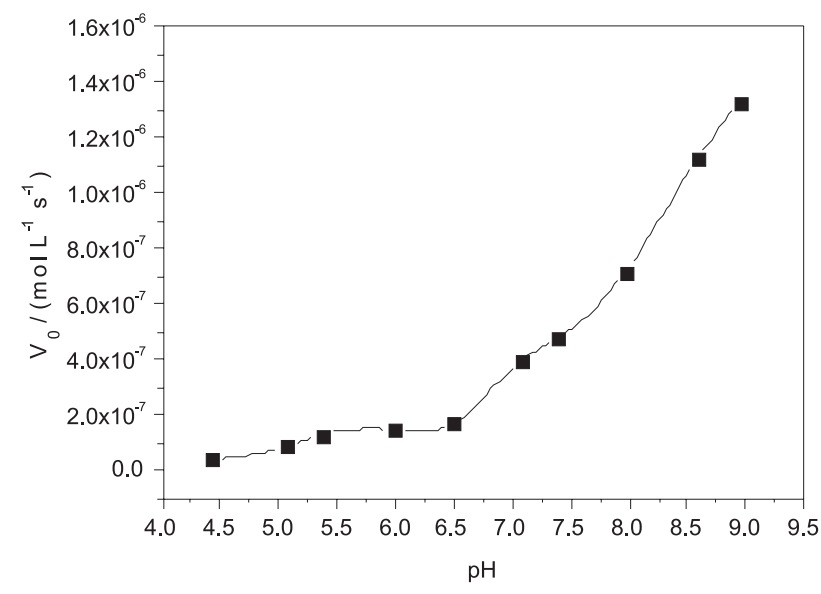

Figure 4. $\mathrm{pH}$ dependence for the oxidation of 3,5-dtbc catalyzed by $\mathbf{1}$. Conditions: $3: 2 \mathrm{CH}_{3} \mathrm{OH}: \mathrm{H}_{2} \mathrm{O},[\mathbf{1}]=1.39 \times 10^{-5} \mathrm{~mol} \mathrm{~L}^{-1},[3,5-\mathrm{dtbc}]=$ $2.77 \times 10^{-3} \mathrm{~mol} \mathrm{~L}^{-1}$, [buffer] $=3.3 \times 10^{-2} \mathrm{~mol} \mathrm{~L}^{-1}($ buffer $=$ MES or TRIS $)$.

The dependence of the initial rates on the concentration of 3,5-dtbc using complex $\mathbf{1}$ as the catalyst was investigated at $25^{\circ} \mathrm{C}$ at $\mathrm{pH} 6.0$ and revealed saturation kinetics with Michaelis-Menten-like behavior (Figure 5).

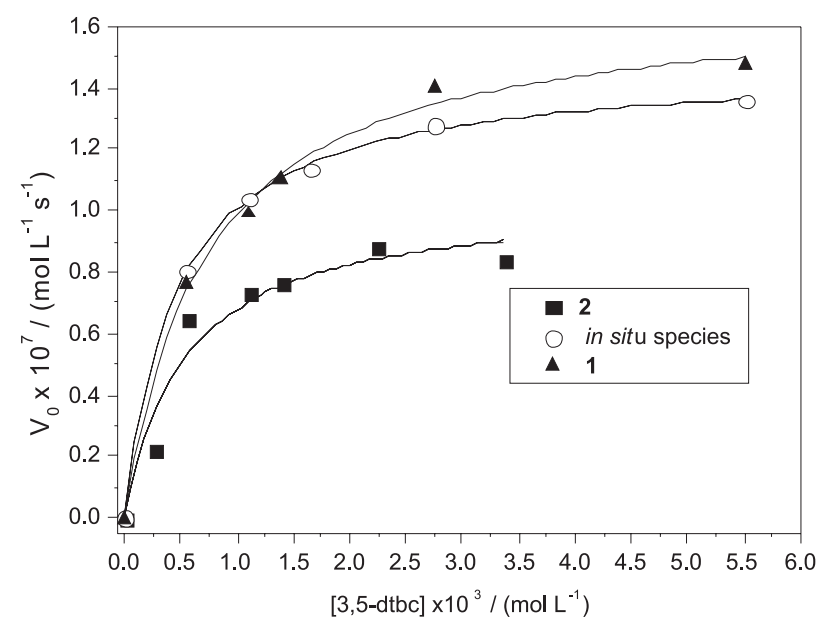

Figure 5. Oxidation of 3,5-dtbc catalyzed by $1(\mathbf{\Lambda}), \mathbf{2}(\mathbf{\square})$ and oxidized complex generated in situ ( 1 with one equivalent of $\left.\mathrm{H}_{2} \mathrm{O}_{2}\right)(\mathrm{O})$ : Dependence of the reaction rates on [3,5-dtbc] at $\mathrm{pH} 6.0$, in a methanol/ water (3:2) solution. Conditions: $[\mathbf{1}]=1.5 \times 10^{-5} \mathrm{~mol} \mathrm{~L}^{-1} ;[3,5-\mathrm{dtbc}]=$ $0.5-5.5 \times 10^{-3} \mathrm{~mol} \mathrm{~L}^{-1}$, [buffer] $=3.3 \times 10^{-2} \mathrm{~mol} \mathrm{~L}^{-1}($ buffer $=$ MES $)$. 
The kinetic parameters $\left(\mathrm{V}_{\max }=1.69 \times 10^{-7} \mathrm{~mol} \mathrm{~L}^{-1} \mathrm{~s}^{-1}\right.$, $K_{\mathrm{M}}=7.1 \times 10^{-4} \mathrm{~mol} \mathrm{~L}^{-1}$ and $\left.k_{\text {cat }}=11.6 \times 10^{-3} \mathrm{~s}^{-1}\right)$, where $K_{\mathrm{M}}$ and $k_{\text {cat }}$ are the Michaelis-Menten and the catalytic constants, respectively, were obtained from Michaelis-Menten nonlinear treatment $\left(\mathrm{V}_{0}\right.$ vs. [3,5-dtbc]). The kinetic parameters obtained for the reaction catalyzed by 2 are in the same order as those found for complex $\mathbf{1}$ in the presence of oxygen or $\mathrm{H}_{2} \mathrm{O}_{2}$ (Table 4), thus supporting the mechanistic proposal that the $\mathrm{Fe}^{\mathrm{III}} \mathrm{Fe}^{\mathrm{III}}$ species must be present to initiate the catalytic cycle. Moreover, accumulation of $\mathrm{H}_{2} \mathrm{O}_{2}$ during turnover was confirmed by means of the molybdateaccelerated $\mathrm{I}_{3}^{-}$assay, which indicates that reoxidation of the $\mathrm{Fe}^{\mathrm{II}} \mathrm{Fe}^{\mathrm{II}}$ species back to the active $\mathrm{Fe}^{\mathrm{III}} \mathrm{Fe}^{\mathrm{III}}$ species occurs with a 1:1 $\left(\mathrm{O}_{2}: 3,5-\mathrm{dtbc}\right)$ stoichiometry and concomitant formation of hydrogen peroxide.

Table 4. Kinetic parameters of the oxidation reaction of the substrate 3,5-dtbc

\begin{tabular}{llll}
\hline & $\mathbf{1}$ & $\mathbf{2}$ & $\mathbf{1}+\mathrm{H}_{2} \mathrm{O}_{2}(1: 1)$ \\
\hline $\mathrm{V}_{\text {max }} /\left(\mathrm{mol} \mathrm{L}^{-1} \mathrm{~s}^{-1}\right)$ & $1.69 \times 10^{-7}$ & $1.04 \times 10^{-7}$ & $1.48 \times 10^{-7}$ \\
$k_{\text {cat }} /\left(\mathrm{s}^{-1}\right)$ & $11.6 \times 10^{-3}$ & $6.34 \times 10^{-3}$ & $9.63 \times 10^{-3}$ \\
$K_{\mathrm{M}} /\left(\mathrm{mol} \mathrm{L}^{-1}\right)$ & $7.1 \times 10^{-4}$ & $5.3 \times 10^{-4}$ & $4.7 \times 10^{-4}$ \\
$\left(k_{\text {cat }} / K_{\mathrm{M}}\right) /\left(\mathrm{L} \mathrm{mol}^{-1} \mathrm{~s}^{-1}\right)$ & 16.33 & 11.96 & 20.48 \\
\hline
\end{tabular}

Finally, papers found in the literature related to catechol artificial biomimetics generally refer to binuclear $\mathrm{Cu}^{\mathrm{II}}$ complexes. ${ }^{43-45,55}$ It is interesting to note that the kinetic parameters obtained in this study for complex $\mathbf{1}$ or complex $\mathbf{2}$ are of the same order as those found for $\mathrm{Cu}^{\mathrm{II}} \mathrm{Cu}^{\mathrm{II}}$ complexes with similar ligands, but with $\mathbf{1}$ or $\mathbf{2}$ being active at lower $\mathrm{pH}$ values $(6.0 \mathrm{vs} .8-9),{ }^{43-45}$ which is a consequence of the higher Lewis acidity of $\mathrm{Fe}^{\mathrm{III}}$ when compared to $\mathrm{Cu}^{\mathrm{II}}$.
Considering all of the experimental data obtained, the mechanism shown in Scheme 3 is proposed.

\section{DNA cleavage}

To verify the ability of complex 1 to cleave DNA phosphodiester bonds, we tested its activity in the absence and in the presence of oxygen. Data from the experiments under aerobic and anaerobic conditions (Figure 6) suggest that a hydrolytic mechanism is responsible for the DNA cleavage, since the reaction is not affected by the absence of oxygen. The control experiment with $\mathrm{Fe}(\mathrm{edta})^{2-} /$ dithiothreitol demonstrated that there is no residual oxygen because DNA cleavage was totally inhibited under anaerobic conditions.

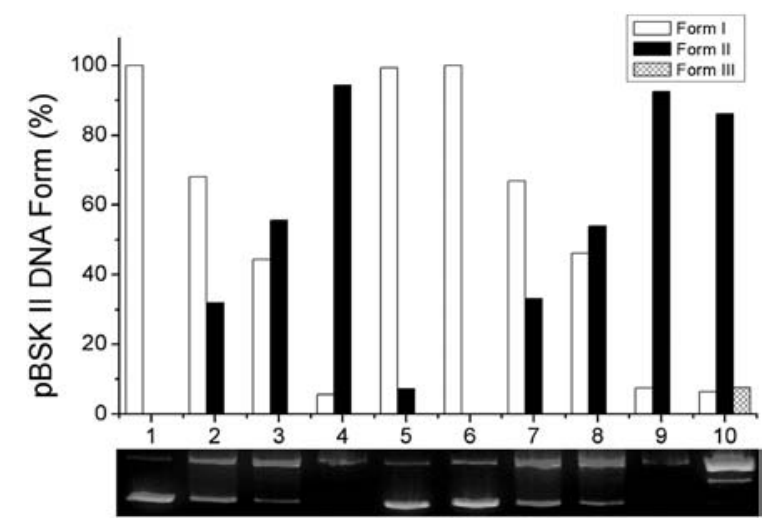

Figure 6. Plasmid DNA cleavage by complex 1 in anaerobic (lanes 1-5) and aerobic (lanes 6-10) conditions. Lanes 1 and 6 control DNA (pBSK-II $35 \mu \mathrm{mol} \mathrm{L} \mathrm{L}^{-1} \mathrm{bp}$ ); lanes 2 and 7: DNA + complex 1, $40 \mu \mathrm{mol} \mathrm{L}^{-1}$; lanes 3 and 8: DNA + complex 1, $80 \mu \mathrm{mol} \mathrm{L}^{-1}$; lanes 4 and 9: DNA + complex 1, $160 \mu \mathrm{mol} \mathrm{L}^{-1}$; lanes 5 and 10: DNA + Fe(edta $)^{2-} 25 \mathrm{mmol} \mathrm{L}^{-1}+\mathrm{DTT}$ $2.5 \mathrm{mmol} \mathrm{L}^{-1}$. Samples were incubated for $2 \mathrm{~h}$ at $50{ }^{\circ} \mathrm{C}, 25 \mathrm{mmol} \mathrm{L}^{-1}$ PIPES pH 6.0

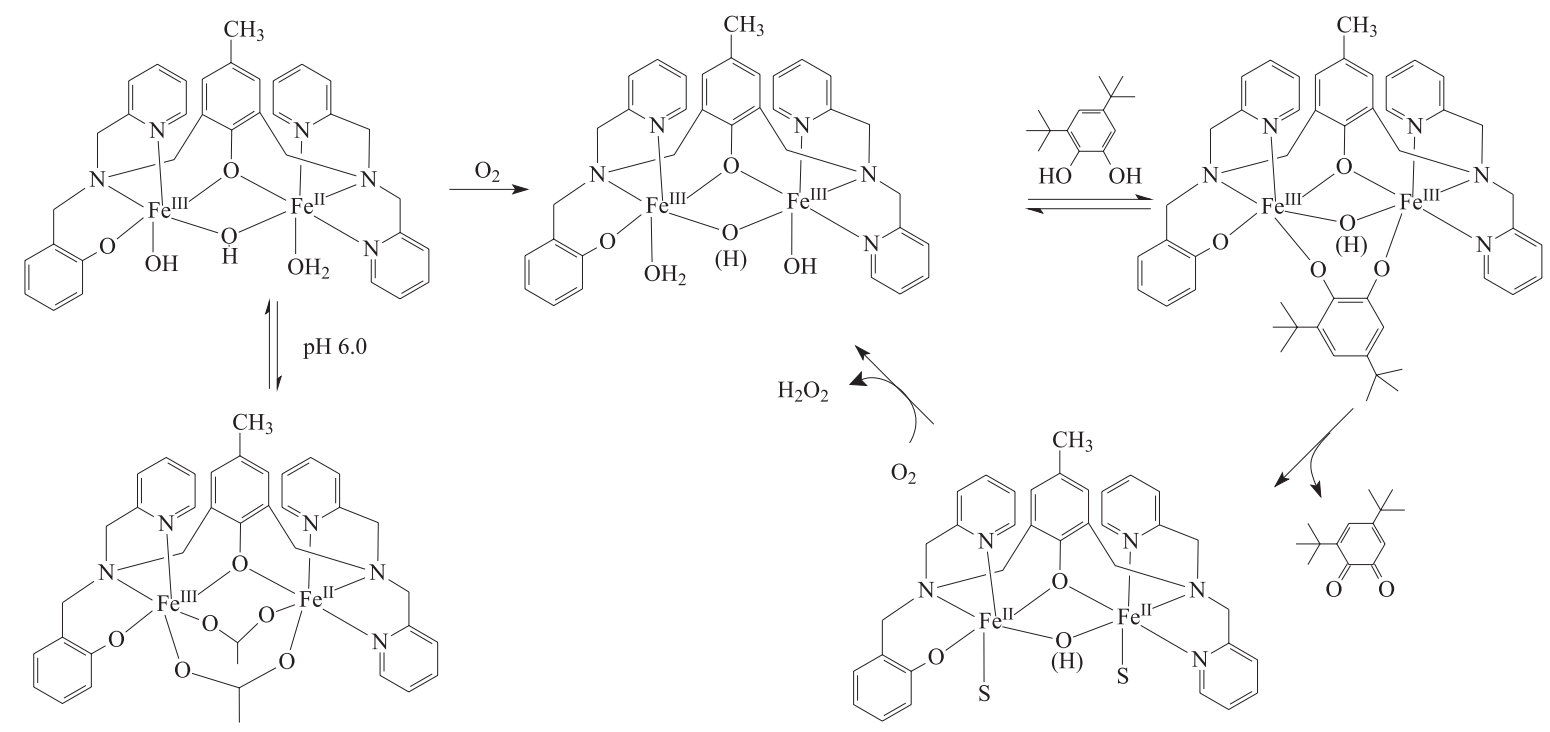

Scheme 3. Proposed mechanism for oxidation of 3,5-dtbc by $\mathbf{1}$. 
It is also clear from Figure 6 that $\mathbf{1}$ was able to cleave plasmid DNA in a concentration-dependent manner. An increase in circular (nicked, form II) plasmid DNA, and a proportional decrease in supercoiled DNA (form I) was observed with increasing complex concentration.

Pseudo-Michaelis-Menten conditions were used in the kinetic studies of the DNA cleavage by $\mathbf{1}^{48,56,57} \mathrm{We}$ observed that the decrease in supercoiled DNA fitted a single exponential decay curve (Figure 7). Cleavage rates at various concentrations of $\mathbf{1}\left(40-160 \mu \mathrm{mol} \mathrm{L} \mathrm{L}^{-1}\right)$ and a constant DNA concentration were calculated and a plot of $k_{\text {obs }}$ versus the concentration of $\mathbf{1}$ shows saturation behavior. Lineweaver-Burk linearization of these data (inset Figure 7) gives the following kinetics parameters: $k_{\text {cat }} 1.91 \times 10^{-3} \mathrm{~s}^{-1}$; $K_{\mathrm{M}} 7.96 \times 10^{-4} \mathrm{~mol} \mathrm{~L}^{-1} ; k_{\text {cat }} / K_{\mathrm{M}} 2.40 \mathrm{~mol} \mathrm{~s}^{-1} \mathrm{~L}^{-1}$, providing a rate enhancement of $1.91 \times 10^{8}$ over the uncatalyzed doublestrand DNA cleavage.

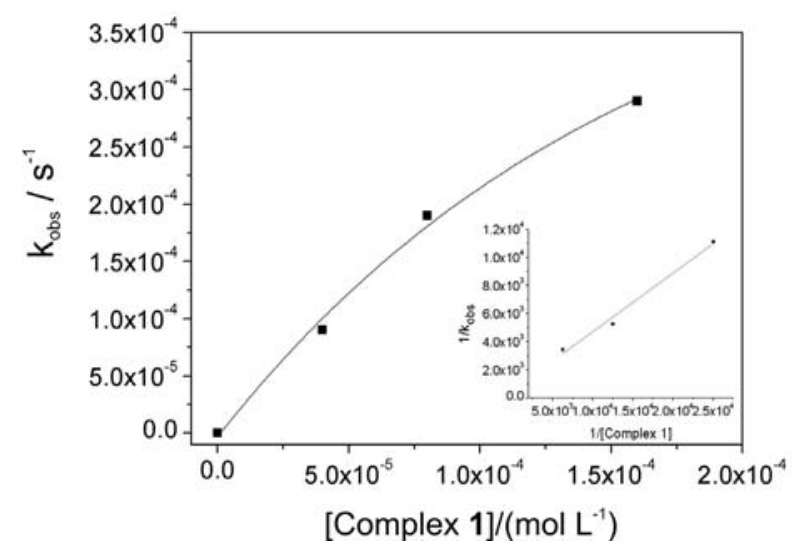

Figure 7. Kinetic analysis of DNA cleavage by $\mathbf{1}$. Final complex concentration varied from 40 to $160 \mu \mathrm{mol} \mathrm{L} \mathrm{L}^{-1}$. Reactions were carried out in $25 \mathrm{mmol} \mathrm{L}^{-1}$ PIPES pH 6.0 at $50{ }^{\circ} \mathrm{C}$ and $k_{\text {obs }}$ was calculated for each concentration.

Figure 8 presents the results of DNA cleavage by 1 in the presence of potential inhibiting agents: a hydroxyl radical scavenger (dmso), a singlet oxygen scavenger (sodium azide, $\mathrm{NaN}_{3}$ ) and a DNA minor groove binder (distamycin). Neither dmso nor sodium azide interfered with the cleavage activity of the complex. These results are in agreement with those found under anaerobic conditions, demonstrating that 1 cleaves DNA hydrolytically and that oxygen radicals are not involved in the reaction. Also in Figure 8, the activity of $\mathbf{1}$ is not inhibited by distamycin, suggesting that $\mathbf{1}$ interacts with double strand DNA through the major grove.

\section{Conclusions}

The complexes $\left[(\right.$ bpbpmp $\left.) \mathrm{Fe}^{\mathrm{III}}(\mu-\mathrm{OAc})_{2} \mathrm{Fe}^{\mathrm{II}}\right]\left(\mathrm{ClO}_{4}\right)(\mathbf{1})$ and $\left[(\right.$ bpbpmp $\left.) \mathrm{Fe}^{\mathrm{III}}(\mu-\mathrm{OAc})_{2} \mathrm{Fe}^{\mathrm{III}}\right]\left(\mathrm{ClO}_{4}\right)_{2}$ (2) containing the unsymmetrical dinucleating ligand $\mathrm{H}_{2}$ bpbpmp,

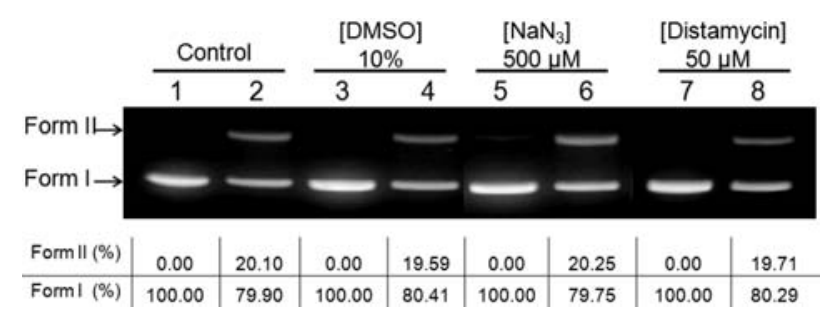

Figure 8. DNA cleavage in the presence of radical scavengers (dmso and $\mathrm{NaN}_{3}$ ) and DNA minor grove binder (distamycin). Final concentration in $20 \mu \mathrm{L}$ reaction of dmso, $\mathrm{NaN}_{3}$ and distamycin are indicated in the figure. Control samples for plasmid DNA with acetonitrile (lane 1), dmso (lane 3), $\mathrm{NaN}_{3}$ (lane 5) and distamycin (lane 7). Lanes 2, 4, 6 and 8 in the presence of $160 \mu \mathrm{mol} \mathrm{L}^{-1}$ complex 1 and the inhibitors indicated.

2-\{[(2-hydroxybenzyl)(2-pyridylmethyl)aminomethyl]4-methyl-6-[bis(2-pyridylmethyl)aminomethyl]\} phenol, were synthesized and their properties and catalytic features explored. The X-ray structure of $\mathbf{1}$ reveals an $\left\{\mathrm{Fe}^{\mathrm{III}}\left(\mu-\mathrm{O}_{\text {phenolate }}\right)(\mu-\mathrm{OAc})_{2} \mathrm{Fe}^{\mathrm{II}}\right\}$ core in which the $\mathrm{Fe}^{\mathrm{III}}$ and $\mathrm{Fe}^{\mathrm{II}}$ metal centers are, respectively, bound by the hard and soft side of the bpbpmp ${ }^{2-}$ ligand. Kinetic studies on the cleavage of double strand DNA (dsDNA) by $\mathbf{1}$ at the optimum $\mathrm{pH}$ (6.0) and $50{ }^{\circ} \mathrm{C}$ show Michaelis-Menten behavior with a rate enhancement of $1.9 \times 10^{8}$ over the uncatalyzed reaction. Data from the experiments under aerobic and anaerobic conditions along with kinetic studies on a model diester substrate suggest a hydrolytic mechanism in which a terminal $\mathrm{Fe}^{\mathrm{III}}$-bound hydroxide is the initiating nucleophile in the catalytic reaction. On the other hand, when the $\left[(\text { bpbpmp })(\mathrm{HO}) \mathrm{Fe}^{\mathrm{III}}(\mu-\mathrm{OH}) \mathrm{Fe}^{\mathrm{II}}\left(\mathrm{H}_{2} \mathrm{O}\right)\right]^{+}$ species is exposed to air, the oxidized $\mathrm{Fe}^{\mathrm{III}} \mathrm{Fe}^{\mathrm{III}}$ complex is formed. This complex shows significant catecholase activity in the oxidation of 3,5-di-tert-butylcatechol (methanol/water buffer, 60:40, $\mathrm{pH}=5.8$ ) and the reaction follows Michaelis-Menten behavior with $k_{\text {cat }}=1.16 \times 10^{-2} \mathrm{~s}^{-1}$ and $K_{\mathrm{M}}=7.1 \times 10^{-4} \mathrm{~mol} \mathrm{~L}^{-1}$. The complex is thus revealed to be an important example of a synthesized promiscuous catalyst, with activity in both the oxidation of catechols and the hydrolysis of phosphodiester bonds.

\section{Supplementary Information}

Figures S1-S4 are available free of charge at http://jbcs.sbq.org.br, as a PDF file. Crystallographic data (excluding structural factors) for the structures in this paper have been deposited with the Cambridge Crystallographic Data Centre as supplementary publication number CCDC 747619. Copies of the data can be obtained free of charge via www.ccdc.cam.ac.uk/conts/retrieving.html (or from the Cambridge Crystallographic Data Centre, CCDC, 12 Union Road, Cambridge CB2 1EZ, UK ; fax: +44 1223336033 ; or e-mail: deposit@ccdc.cam.ac.uk). 


\section{Acknowledgments}

The authors thank CNPq, CAPES, FAPESC and INCT-Catálise for financial support. G. Schenk and L. Gahan acknowledge funds awarded by the Australian Research Council through grants DP0986292, DP0986613, DP0664039 and DP0558652.

\section{References}

1. Kazlauskas, R. J.; Curr. Opin. Chem. Biol. 2005, 9, 195.

2. Bornscheuer, W. T.; Kazlauskas, R. J.; Angew. Chem. 2004, 43, 6032.

3. O’Brian, P. J.; Herschlag, D.; Chem. Biol. 1999, 6, 91.

4. Taglieber,A.; Höbenreich,H.; Carballeira,J.D.; Mondière, R. J.G.; Reetz, M. T.; Angew. Chem. 2007, 46, 8597 and references therein. 5. O'Brian, P. J.; Chem. Rev. 2006, 106, 720 and references therein. 6. Olguin, L. F.; Askew, S. E.; O’Donoghue, A. C.; Hollfelder, F.; J. Am. Chem. Soc. 2008, 130, 16547.

7. Zalatan, J. G.; Herschlag, D.; J. Am. Chem. Soc. 2006, 128, 1293.

8. Hemrika, W.; Renirie, R.; Dekker, H. L.; Barnett, P.; Wever, R.; Proc. Natl. Acad. Sci. USA 1997, 94, 2145.

9. Yoneyama, T.; Shiozawa, M.; Nakamura, M.; Suzuki, T.; Sagane, Y. Katoh, Y.; Watanabe, T.; Ohyama, T.; J. Biol. Chem. 2004, 279, 37477.

10. Bozzo, G. G.; Raghothama, K. G.; Plaxton, W. C.; Eur. J. Biochem. 2002, 269, 6278.

11. Kenton, P.; Mur, L. A. J.; Draper, J.; J. Exp. Bot. 1999, 50, 1331.

12. Jakobek, J. L.; Lindgren, P. B.; J. Exp. Bot. 2002, 53, 387.

13. Oliveira, M. C. B.; Scarpellini, M.; Neves, A.; Terenzi, H.; Bortoluzzi,A.J.;Szpoganicz, B.; Greatti,A.; Mangrich,A.S.; Souza, E. M.; Fernandez, P. M.; Soares, M.; Inorg. Chem. 2005, 44, 921.

14. Rey, N. A.; Neves, A.; Bortoluzzi, A. J.; Pich, C. T.; Terenzi, H.; Inorg. Chem. 2007, 46, 348.

15. Deck, K. M.; Tseng, T. A.; Burstyn, J. N.; Inorg. Chem. 2002, 41,669 .

16. Hegg, E. L.; Burstyn, J. N.; J. Am. Chem. Soc. 1995, 117, 7015.

17. Hegg, E. L.; Burstyn, J. N.; Inorg. Chem. 1996, 35, 7474.

18. Parrilha, G. L.; Fernandes, C.; Bortoluzzi, A. J.; Szpoganicz, B.; Silva, M. S.; Pich, C. T.; Terenzi, H.; Horn, A., Jr.; Inorg. Chem. Commun. 2008, 11, 643.

19. Mitic, N.; Smith, S. J.; Neves, A.; Guddat, L. W.; Gahan, L. R.; Schenk, G.; Chem. Rev. 2006, 106, 3338.

20. Gavrilova, A. L.; Bosnich, B.; Chem. Rev. 2004, 104, 349;

21. Gahan, L. R.; Smith, S. J.; Neves, A.; Schenk, G.; Eur. J. Inorg. Chem. 2009, 2745.

22. Neves, A.; Lanznaster, M.; Bortoluzzi, A. J.; Peralta, R. A.; Casellato, A.; Castellano, E. E.; Herrald, P.; Riley, M. J.; Schenk, G.; J. Am. Chem. Soc. 2007, 129, 7486.

23. Karsten, P.; Neves, A.; Bortoluzzi, A. J.; Drago, V.; Lanznaster, M.; Inorg. Chem. 2002, 41, 4624.
24. Karsten, P.; Neves, A.; Bortoluzzi, A. J.; Strähle, J.; MaichleMössmer, C.; Inorg. Chem. Commun. 2002, 5, 434.

25. Batista, S. C.; Neves, A.; Bortoluzzi, A. J.; Vencato, I.; Peralta, R. A.; Szpoganicz, B.; Aires, V. E.; Severino, P. A.; Inorg. Chem. Commun. 2003, 6, 1161.

26. Lanznaster, M.; Neves, A.; Bortoluzzi, A. J.; Aires, V. V. E.; Szpoganicz, B.; Terenzi, H.; Severino, R. C.; Fuller, J. M.; Drew, S. C.; Gahan, L. R.; Hanson, G. R.; Riley, M. J.; Schenk, G.; J. Biol. Inorg. Chem. 2005, 10, 319.

27. Schenk, G.; Peralta, R. A.; Batista, S. C.; Bortoluzzi, A. J.; Szpoganicz, B.; Dick, A. K; Herrald, P.; Hanson, G. R.; Szilagyi, R. K.; Riley, M. J.; Gahan, L. R.; Neves, A.; J. Biol. Inorg. Chem. 2008, 13, 139.

28. Smith, S. J.; Casellato, A.; Hadler, K. S.; Mitić, N.; Riley, M. J.; Bortoluzzi, A. J.; Szpoganicz, B.; Schenck, G.; Neves, A.; Gahan, L.; J. Biol. Inorg. Chem. 2007, 12, 1207.

29. Neves, A.; Brito, M. A.; Drago, V.; Griesar, K.; Haase, W.; Inorg. Chim. Acta 1995, 237, 131.

30. Gonçalves, N. S.; Horn Jr., A.; Lanznaster, M.; Noda, L. K.; Neves, A.; J. Braz. Chem. Soc. 2006, 17, 1658.

31. Smith, S. J.; Jovito, R.; Horn Jr., A.; Nascimento, O. R.; Noble, C. J.; Hanson, G. H.; Stranger, R.; Jayaratne, V.; Cavigliasso, G.; Gahan, L. R.; Schenk, G.; Neves, A.; Riley, M. J.; unpublished results.

32. de Oliveira, I. R.W. Z.; Neves, A.; Vieira, I. C.; Sens. Actuators 2008, B 129, 424.

33. Bernhardt, P. V.; Schenk, G.; Wilson, G.; J. Biochem. 2004, 43, 10387.

34. Wang, D. L.; Holz, R. C.; David, S. S.; Que Jr., L.; Stankovich, M. T.; Biochemistry 1991, 30, 8187.

35. Bunton, C. A.; Farber, S. J.; J. Org. Chem. 1969, 34, 767.

36. Martell, A. E.; Motekaitis, R. J.; Determination of Stability Constants, $2^{\text {nd }}$ ed., VHC Publishers: Weinheim, Germany, 1992.

37. Enraf-Nonius; CAD-4 EXPRESS; Version 5.1/1.2; EnrafNonius: Delft, The Netherlands, 1994.

38. Spek, A.L.; HELENA; CAD-4 Data Reduction Program; Univ. of Utrecht, The Netherlands, 1996.

39. Spek, A.L.; Acta Crystallogr. 1990, A46, C34.

40. North, A. C. T.; Phillips, D. C.; Mathews, F. S.; Acta Crystallogr. 1968, $A 24,351$.

41. Altomare, A.; Burla, M. C.; Camalli, M.; Cascarano, G.; Giacovazzo, C.; Guagliardi, A.; Moliterni, A.G.G.; Polidori, G.; Spagna, R.; J. Appl. Cryst. 1999, 32, 115.

42. Sheldrick, G.M.; Acta Crystallogr. 2008, A64, 112.

43. Neves, A.; Rossi, L. M.; Bortoluzzi, A. J.; Szpoganicz, B.; Wiezbicki, C.; Schwingel Haase, E.; Ostrovsky, W. S.; Inorg. Chem. 2002, 41, 1788.

44. Peralta, R. A.; Neves, A.; Bortoluzzi, A. J.; dos Anjos, A.; Xavier, F. R.; Szpoganicz, B.; Terenzi, H.; de Oliveira, M. C. B.; Castellano, E.; Friedermann, G. R.; Mangrich, A. S.; Novak, M. A.; J. Inorg Biochem. 2006, 100, 992. 
45. Neves, A.; Rossi, L. M.; Bortoluzzi, A. J.; Haase, W.; Werner. R.; J. Braz. Chem. Soc. 2001, 12, 747.

46. Gonzalez-Alvarez, M.; Alzuet, G.; Borras, J.; Macías, B.; Del Olmo, M.; Liu-Gonzalez, M. E.; Sanz, F.; J. Inorg. Biochem. 2002, 89, 29.

47. Scarpellini, M.; Neves, A.; Hörner, R.; Bortoluzzi, A. J.; Szpoganicz, B.; Zucco, C.; Nome, R. A.; Drago, V.; Mangrich. A.S.; Ortiz, W. A.; Passos, W.A.; de Oliveira, M. C.; Terenzi, H.; Inorg. Chem. 2003, 42, 8353.

48. Sreedhara, A.; Freed, J. D. E.; Cowan, J. A.; J. Am. Chem. Soc. 2000, 122, 8814.

49. Brezova, V.; Valko, M.; Breza, H.; Morris, H.; Telser, J.; Dvoranova, D.; Kaiserova, K.; Varecka, L.; Mazur, M.; Leibfritz, D.; J. Phys. Chem. B 2003, 107, 2415.

50. Macías, B.; Villa, M.V.; Gómez, B.; Borrás, J.; Alzuet, G.; González-Álvarez, M.; Castineiras, A.; J. Inorg. Biochem. 2007, $101,444$.

51. Uytterhoeven, K.; Sponer, J.; Van Meervelt, L.; Eur. J. Biochem. 2002, 269, 2868.
52. Lanznaster, M.; Neves, A.; Bortoluzzi, A. J.; Szpoganicz, B.; Schwingel, E.; Inorg. Chem. 2002, 41, 5641.

53. Horn Jr, A.; Vencato, I.; Bortoluzzi, A.J.; Hörner, R.; Silva, R.A.N.; Szpoganicz, B.; Drago, V.; Terenzi, H.; Oliveira, M.C.B.; Werner, R.; Haase. W.; Neves, A.; Inorg. Chim. Acta 2005, 358, 339.

54. Bornscheuer, U. T.; Kazlauskas, R. J.; Angew. Chem. Int. Ed. 2004, 43, 6032.

55. Smith, S. J.; Noble, C. J.; Palmer, R. C.; Hanson, G. R.; Schenk, G.; Gahan, L. R.; Riley, M. J.; J. Biol. Inorg. Chem. 2008, 13, 499.

56. Cowan, J. A.; Curr. Opin. Chem. Biol. 2001, 5, 634.

57. Sreedhara, A.; Cowan, J. A.; J. Biol. Inorg. Chem. 2001, 6, 337.

Received: October 1, 2009 Web Release Date: March 15, 2010 


\section{Catalytic Promiscuity: Catecholase-like Activity and Hydrolytic DNA Cleavage Promoted by a Mixed-Valence $\mathrm{Fe}^{\mathrm{III}} \mathrm{Fe}^{\mathrm{II}}$ Complex}

Ademir Neves, ${ }^{*, a}$ Adailton J. Bortoluzzi, ${ }^{a}$ Rafael Jovito, ${ }^{a}$ Rosely A. Peralta, ${ }^{a}$ Bernardo de Souza, ${ }^{a}$ Bruno Szpoganicz, ${ }^{a}$ Antônio C. Joussef, ${ }^{a}$ Hernán Terenzi, ${ }^{b}$ Patricia C. Severino, ${ }^{b}$ Franciele L. Fischer, ${ }^{b}$ Gerhard Schenk, ${ }^{c}$ Mark J. Riley, ${ }^{c}$ Sarah J. Smith and Lawrence R. Gahan ${ }^{c}$

${ }^{a}$ LABINC, Departamento de Química and ${ }^{b}$ Centro de Biologia Molecular Estrutural, Departamento de Bioquímica, Universidade Federal de Santa Catarina, 88040-900 Florianópolis - SC, Brazil

${ }^{c}$ School of Chemistry and Molecular Biosciences, The University of Queensland, Brisbane 4072, Australia

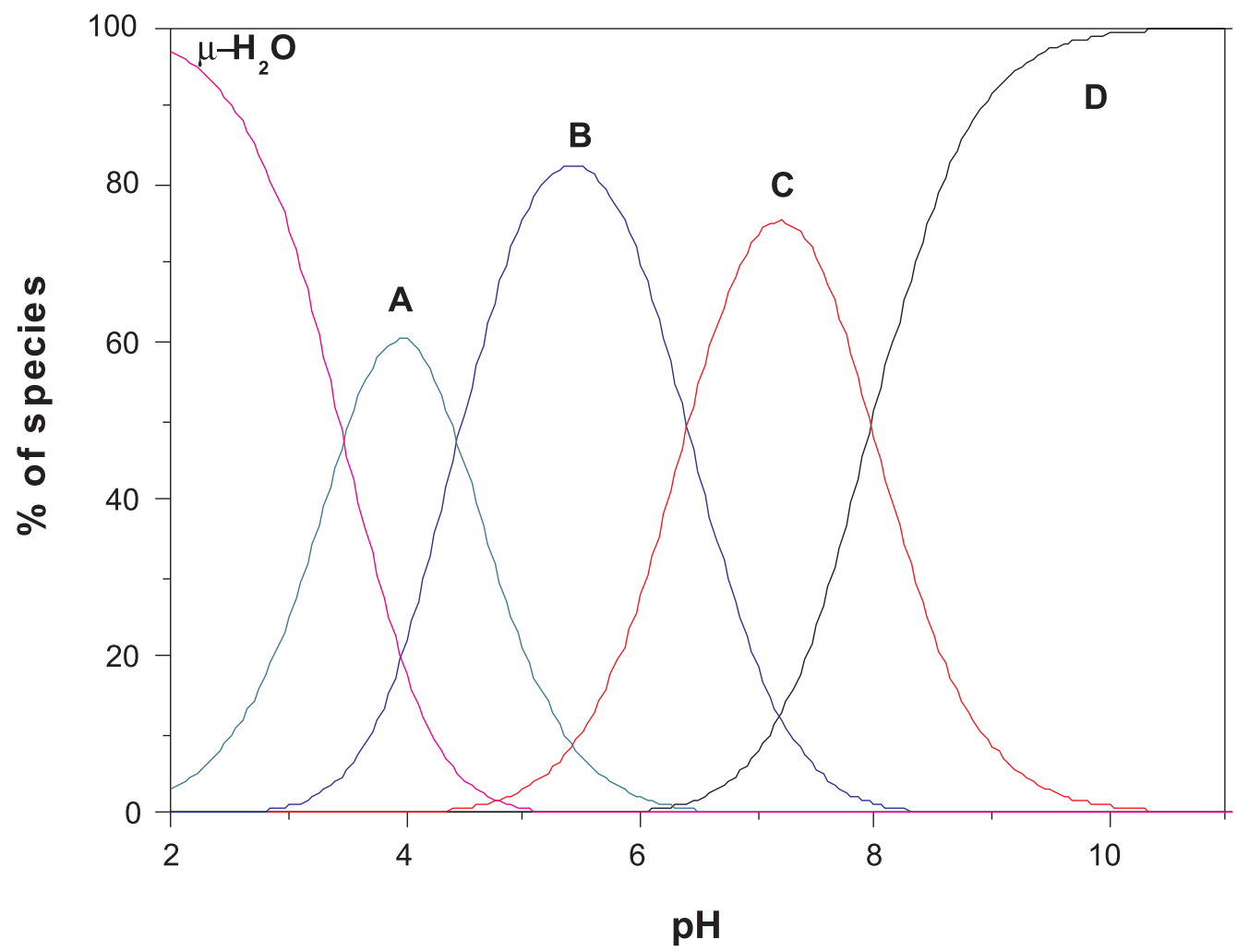

Figure S1. Species diagram for the spectrophotometric titration of complex $\left[\mathrm{Fe}^{\mathrm{III}}(\mathrm{bpbpmp})(\mu-\mathrm{OAc})_{2} \mathrm{Fe}^{\mathrm{II}}\right]^{+}$in $\mathrm{CH}_{3} \mathrm{CN}: \mathrm{H}_{2} \mathrm{O} 1: 1 \cdot \mu-\mathrm{H}_{2} \mathrm{O}:\left[\left(\mathrm{OH}_{2}\right) \mathrm{Fe} \mathrm{III}^{\mathrm{II}}\left(\mathrm{OH}_{2}\right)\right.$ $\left.\mathrm{Fe}^{\mathrm{II}}\left(\mathrm{OH}_{2}\right)\right] ; \mathrm{A}:\left[\left(\mathrm{OH}_{2}\right) \mathrm{Fe}^{\mathrm{III}}(\mu-\mathrm{OH}) \mathrm{Fe}^{\mathrm{II}}\left(\mathrm{OH}_{2}\right)\right] ; \mathrm{B}:\left[(\mathrm{OH}) \mathrm{Fe}^{\mathrm{III}}(\mu-\mathrm{OH}) \mathrm{Fe}^{\mathrm{II}}\left(\mathrm{OH}_{2}\right)\right] ; \mathrm{C}:\left[(\mathrm{OH}) \mathrm{Fe}^{\mathrm{III}}(\mu-\mathrm{O}) \mathrm{Fe}^{\mathrm{II}}\left(\mathrm{OH}_{2}\right)\right] ; \mathrm{D}:\left[(\mathrm{OH}) \mathrm{Fe}^{\mathrm{eII}}(\mu-\mathrm{O}) \mathrm{Fe}^{\mathrm{II}}(\mathrm{OH})\right]$. 


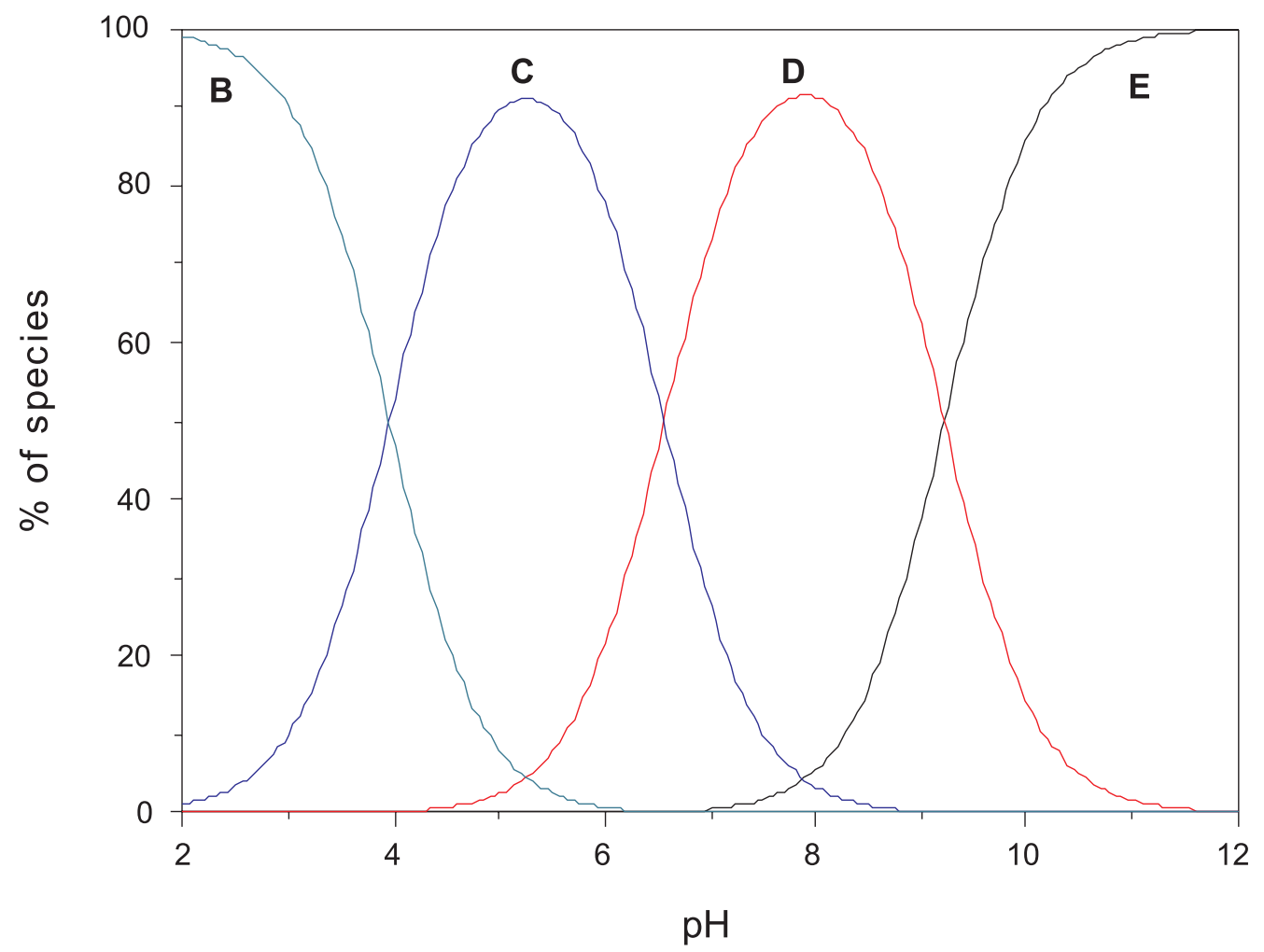

Figure S2. Species diagram for the spectrophotometric titration of complex $\left[\mathrm{Fe}^{\mathrm{III}}(\mathrm{bpbpmp})(\mu-\mathrm{OAc})_{2} \mathrm{Fe}^{\mathrm{III}}\right]^{2+}$ in $\mathrm{CH}_{3} \mathrm{CN}: \mathrm{H}_{2} \mathrm{O} 1: 1 . \mathrm{B}$ : $\left[(\mathrm{OH}) \mathrm{Fe} e^{\mathrm{II}}(\mu-\mathrm{OH})\right.$ $\left.\mathrm{Fe}^{\mathrm{II}}\left(\mathrm{OH}_{2}\right)\right] ; \mathrm{C}:\left[(\mathrm{OH}) \mathrm{Fe}^{\mathrm{II}}(\mu-\mathrm{O}) \mathrm{Fe}^{\mathrm{III}}\left(\mathrm{OH}_{2}\right)\right] ; \mathrm{D}:\left[(\mathrm{OH}) \mathrm{Fe}^{\mathrm{III}}(\mu-\mathrm{O}) \mathrm{Fe}^{\mathrm{III}}(\mathrm{OH})\right] ; \mathrm{E}:\left[(\mathrm{OH}) \mathrm{Fe}^{\mathrm{III}}(\mu-\mathrm{O}) \mathrm{Fe}^{\mathrm{II}}(\mathrm{OH})_{2}\right]$.

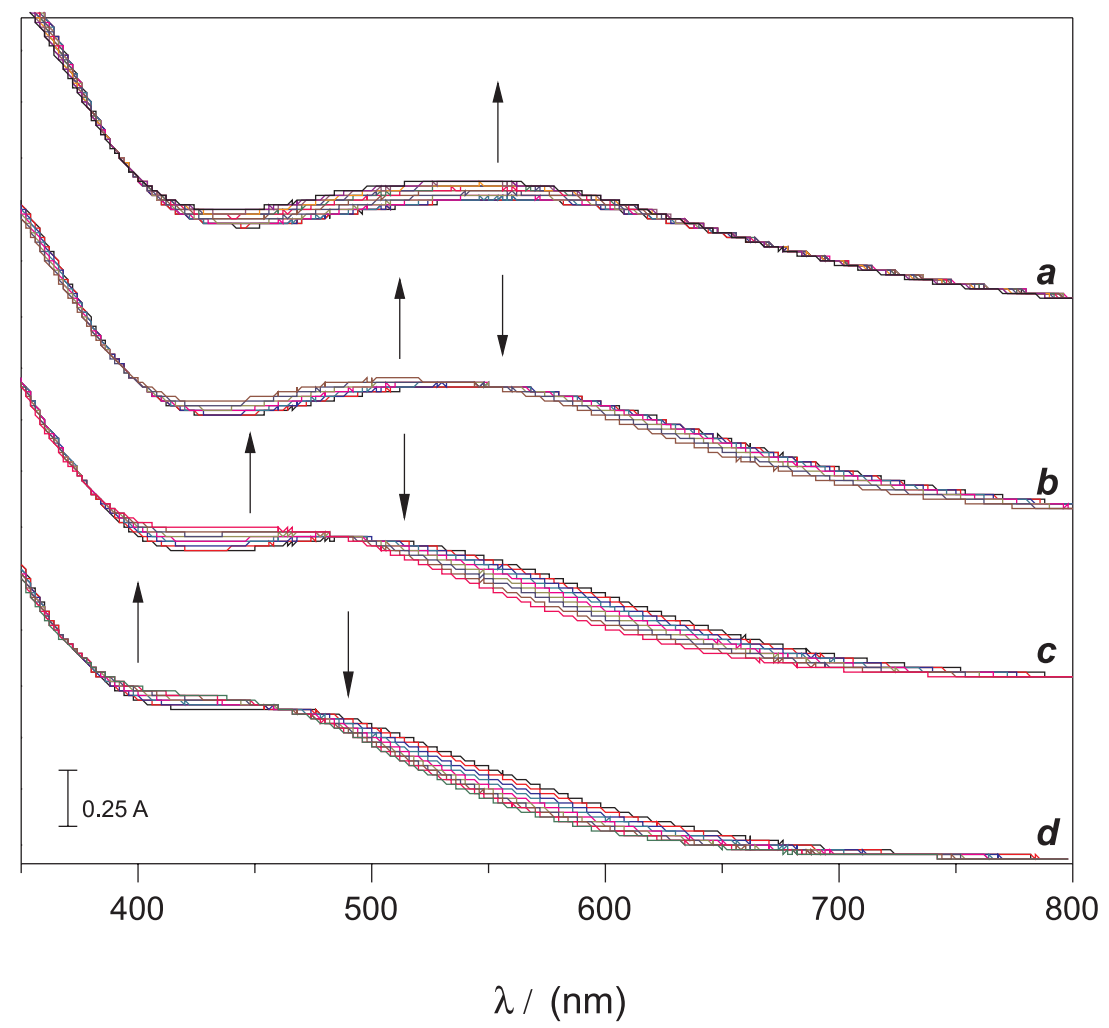

Figure S3. Spectral changes of the complex $\left[\mathrm{Fe}^{\mathrm{II}}(\mathrm{bpbpmp})(\mu-\mathrm{OAc})_{2} \mathrm{Fe}^{\mathrm{II}}\right]^{2+}$ during titration. The spectra were recorded on $\mathrm{CH}_{3} \mathrm{CN}_{2} \mathrm{H}_{2} \mathrm{O} 1: 1$ at successive $\mathrm{pH}$. [complex] $=3 \times 10^{-4} \mathrm{~mol} \mathrm{~L}^{-1}$. pH range $\boldsymbol{a}: 2.4-3.7 ; \boldsymbol{b}: 3.6-4.7 ; \boldsymbol{c}: 5.5-8.1 ; \boldsymbol{d}: 8.1-10.9$. 


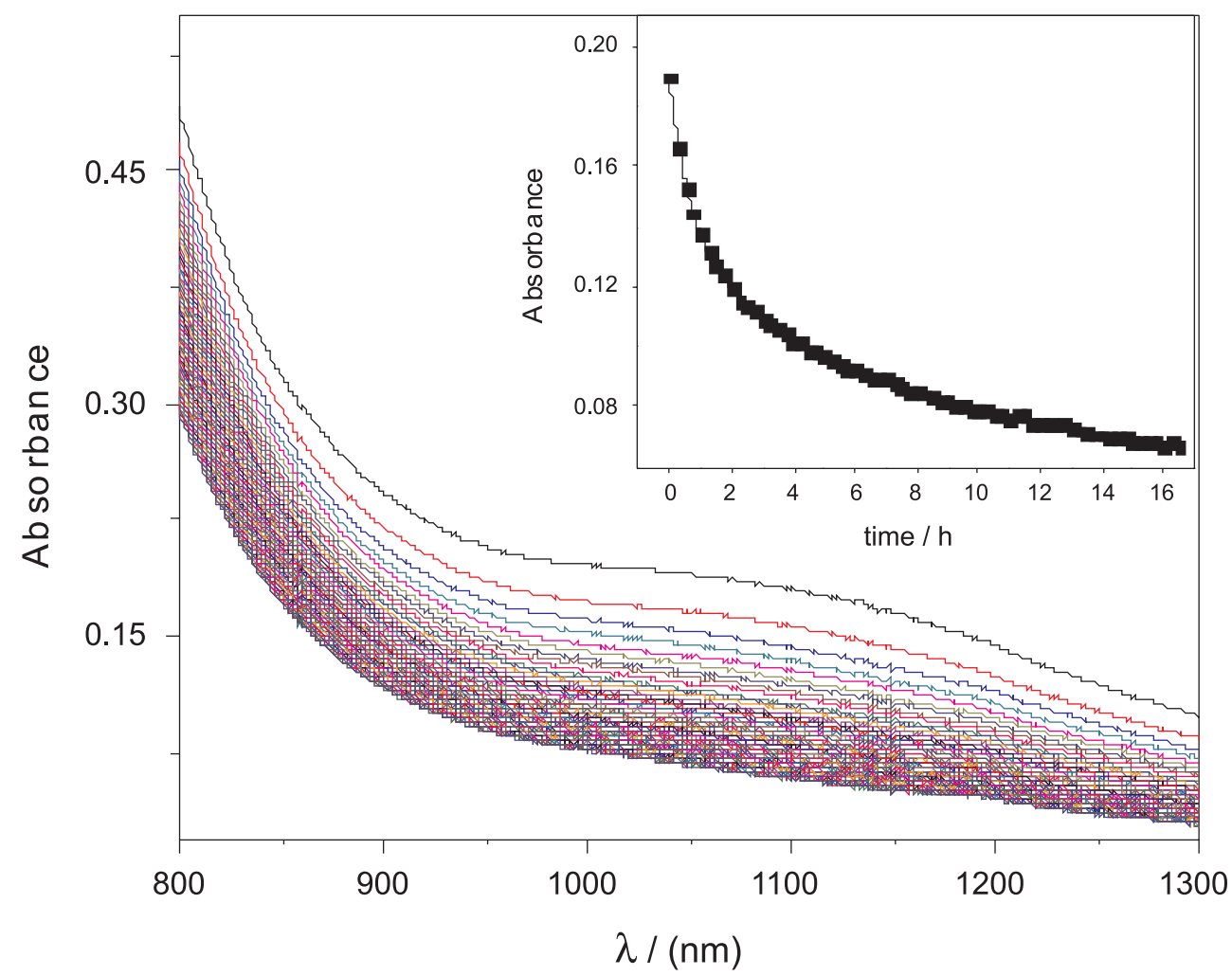

Figure S4. Spectral change of the intervalence band for the mixed-valence complex $\left[\mathrm{Fe}^{\mathrm{III}}(\mathrm{bpbpmp})(\mu-\mathrm{OAc})_{2} \mathrm{Fe}^{\mathrm{II}}\right]^{+}$over time under kinetic conditions: $3: 2$ $\mathrm{CH}_{3} \mathrm{OH}: \mathrm{H}_{2} \mathrm{O}$ at $\mathrm{pH}$ 7.0. [complex] $=4 \times 10^{-3} \mathrm{~mol} \mathrm{~L}^{-1}$, [buffer] $=0.1 \mathrm{~mol} \mathrm{~L}^{-1}$. Inset: Decay of the absorbance at $1050 \mathrm{~nm}$ during $16 \mathrm{~h}$. 